\title{
Preliminary Waste Form Compliance Plan for the Idaho National Engineering and Environmental Laboratory High-Level Waste
}

\author{
B. A. Staples \\ T. P. O'Holleran
}

Published May 1999

\author{
Idaho National Engineering and Environmental Laboratory \\ Nuclear Operations High-Level Waste Program \\ Lockheed Martin Idaho Technologies Company \\ Idaho Falls, Idaho 83415
}





\section{DISCLAIMER}

This report was prepared as an account of work sponsored by an agency of the United States Government. Neither the United States Government nor any agency thereof, nor any of their employees, make any warranty, express or implied, or assumes any legal liability or responsibility for the accuracy, completeness, or usefulness of any information, apparatus, product, or process disclosed, or represents that its use would not infringe privately owned rights. Reference herein to any specific commercial product, process, or service by trade name, trademark, manufacturer, or otherwise does not necessarily constitute or imply its endorsement, recommendation, or favoring by the United States Government or any agency thereof. The views and opinions of authors expressed herein do not necessarily state or reflect those of the United States Government or any agency thereof. 


\section{DISCLAIMER}

Portions of this document may be illegible in electronic image products. Images are produced from the best available original document. 


\section{SUMMARY}

The Department of Energy (DOE) has specific technical and documentation requirements for high-level waste (HLW) that is to be placed in a federal repository. This document describes in general terms the strategy to be used at the Idaho National Engineering and Environmental Laboratory (INEEL) to demonstrate that vitrified HLW, if produced at the INEEL, meets these requirements. Waste form, canister, quality assurance, and documentation specifications are discussed. Compliance strategy is given, followed by an overview of how the strategy would be implemented for each specification. 


\section{CONTENTS}

\section{INTRODUCTION 1}

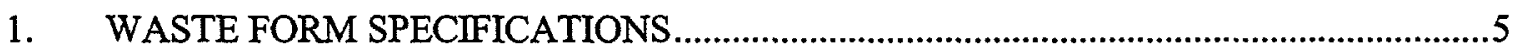

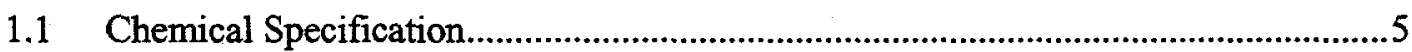

1.1.1 Chemical Composition Projections ................................................................5

1.1.2 Chemical Composition During Production .............................................6

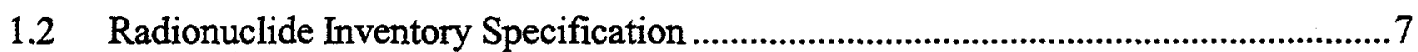

1.2.1 Radionuclide Inventory Projections ...........................................................

1.2.2 Radionuclide Inventory During Production ...........................................

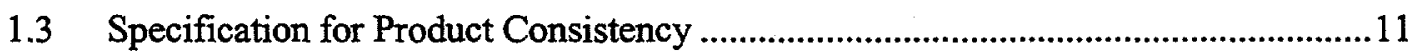

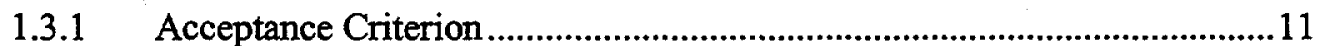

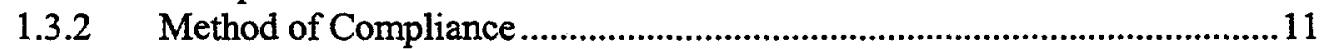

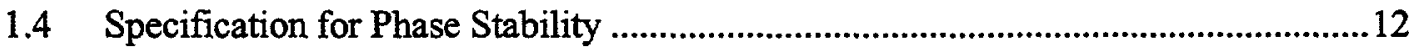

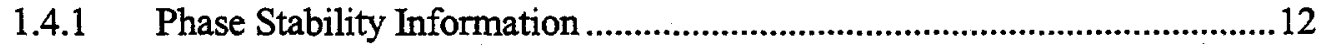

1.4.2 Control of Temperature for Phase Stability ...............................................13

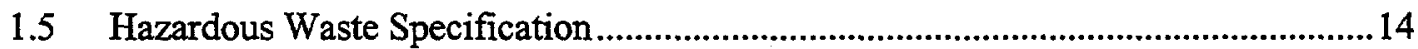

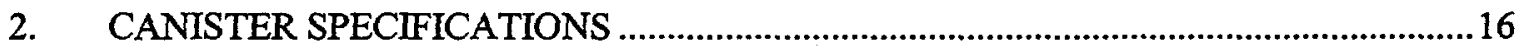

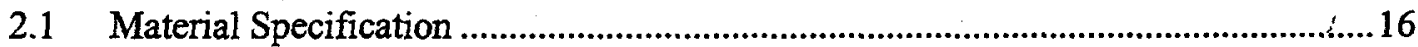

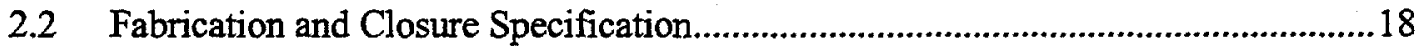

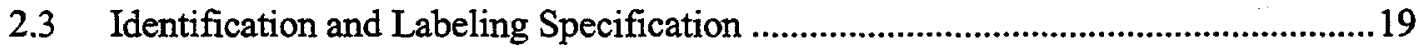

2.3.1 Identification and Labeling................................................................... 19

2.4 Specification for Canister Length and Diameter .................................................21

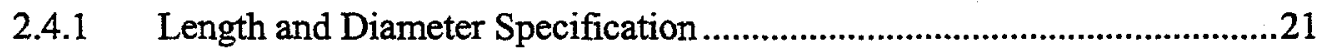

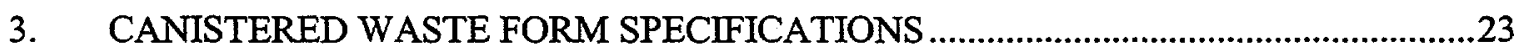

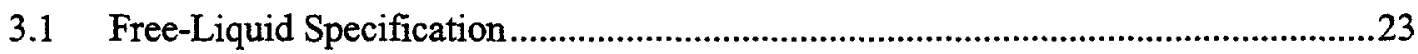

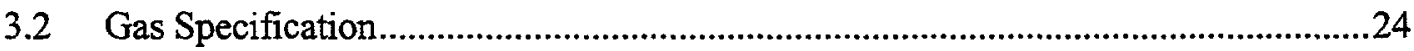

3.3 Specification for Explosiveness, Pyrophoricity, and Combustibility .......................25

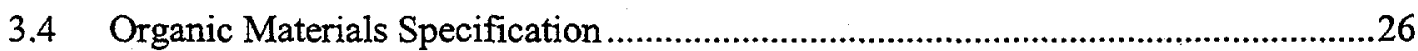


3.5 Chemcical Compatibility Specification...............................................................26

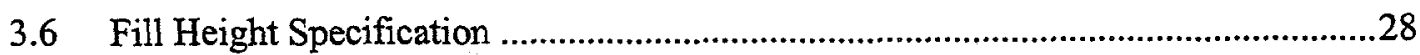

3.7 Specification for Removable Contamination on External Surfaces ........................28

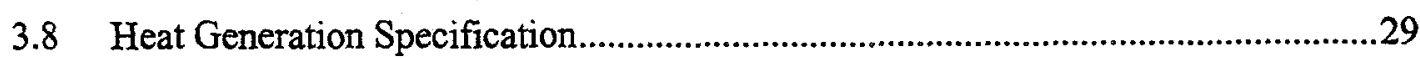

3.8.1 Heat Generation Projections.................................................................29

3.8.2 Heat Generation at Year of Shipment .......................................................30

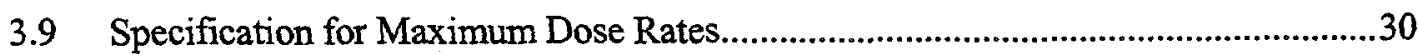

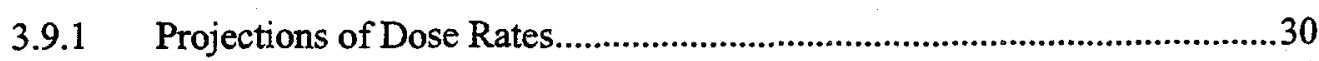

3.9.2 Dose Rates at Time of Shipment .................................................................

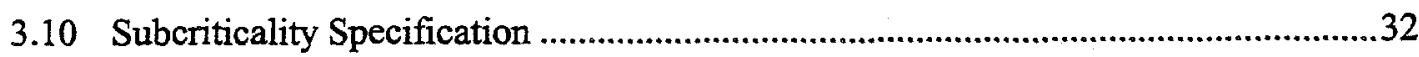

3.11 Specifications for Weight and Overall Dimensions .............................................33

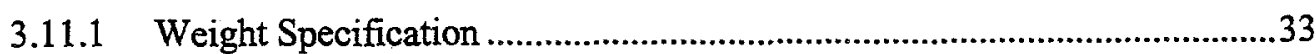

3.11.2 Specification for Overall Dimensions ......................................................33

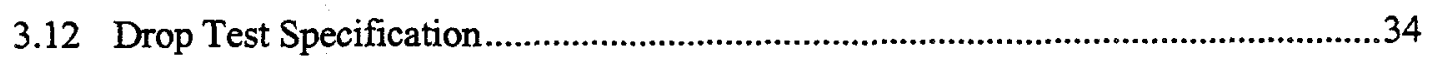

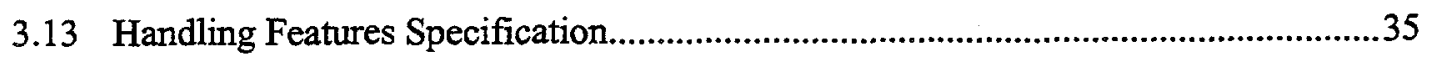

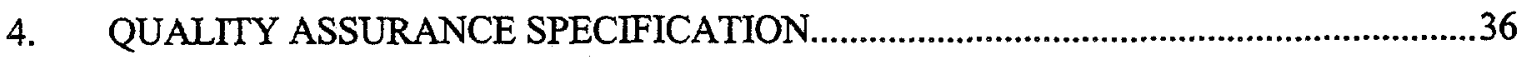

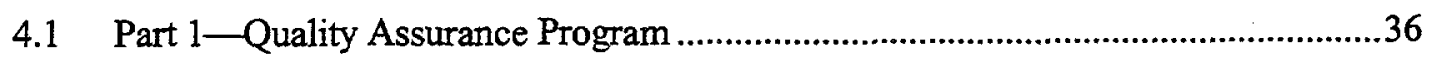

4.1.1 SNF/NM QPP Development .................................................................36

4.1.2 Identification of DOE-RW QARD Applicable Items,
Services, and Activities

4.1.3 Qualification of Existing Data .................................................................37

4.2 Part 2-Action Plan for Nonconforming Waste Forms .........................................37

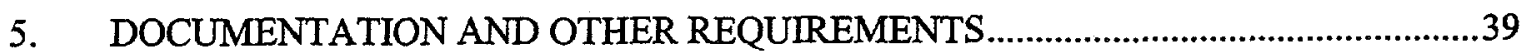

5.1 Specification for Waste Acceptance Documentation .............................................39

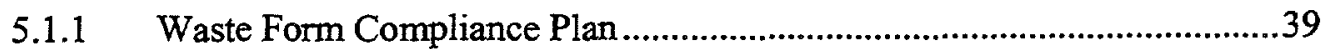

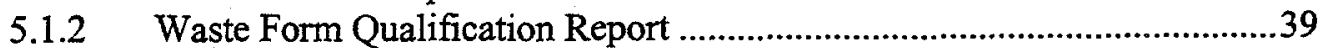

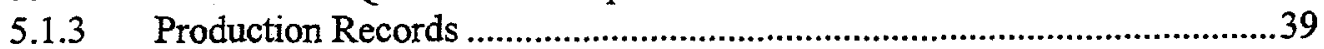

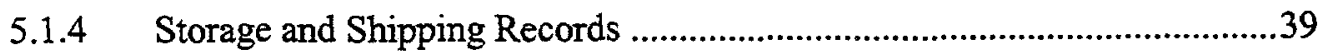

REFERENCES 


\section{FIGURES}

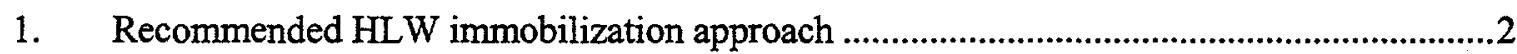

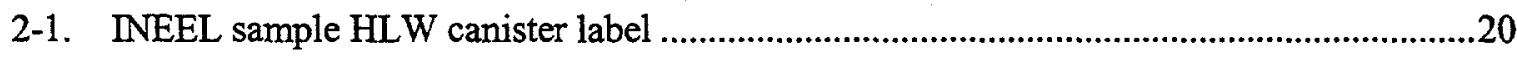

\section{TABLES}

1-1. Estimated total quantities of radionuclides with half lifes greater than 10 grams ................8

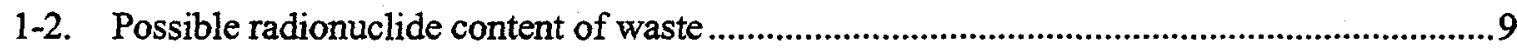

2-1. Chemical composition requirements for ASTM A240 Type 304L stainless steel (S30403).

2-2. Chemical composition requirement of Type 308L stainless steel weld metal, ER 308L (W30843)

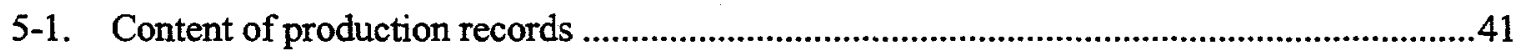

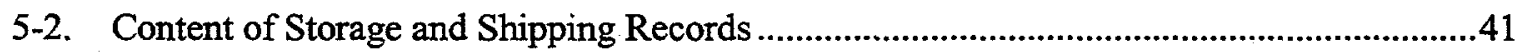




\section{ACRONYMS}

\begin{tabular}{|c|c|}
\hline ASME & American Society of Mechanical Engineers \\
\hline ASTM & American Society for Testing and Materials \\
\hline CFR & - Code of Federal Regulations \\
\hline CSSF & Calcined Solids Storage Facilities \\
\hline DOE & Department of Energy \\
\hline$-E M$ & Office of Environmental Management \\
\hline$-\mathrm{ID}$ & Idaho Operations Office \\
\hline$-R W$ & Office of Civilian Radioactive Waste Management \\
\hline DWPF & Defense Waste Processing Facility \\
\hline EA & Environmental Assessment \\
\hline HAW & High Activity Waste \\
\hline HLLW & High-level Liquid Waste \\
\hline HLW & High-level Waste \\
\hline ICPP & Idaho Chemical Processing Plant \\
\hline NNEEL & Idaho National Engineering and Environmental Laboratory \\
\hline NNTEC & Idaho Nuclear Technology and Engineering Center \\
\hline LAW & Low Activity Waste \\
\hline LDR & Land Disposal Restriction \\
\hline LLW & Low-Level Waste \\
\hline LMITCO & Lockheed Martin Idaho Technologies Company \\
\hline NM & Nuclear Material \\
\hline PCP & Process Control Program \\
\hline PCT & Product Consistency Test \\
\hline PWCP & Preliminary Waste Form Compliance Plan \\
\hline QA & Quality Assurance \\
\hline QAPD & Quality Assurance Program Description \\
\hline QARD & Quality Assurance Requirements and Description \\
\hline QPP & Quality Program Plan \\
\hline R\&D & Research and Development \\
\hline RCRA & Resource Conservation and Recovery Act \\
\hline
\end{tabular}


$\mathrm{T}_{\mathrm{g}}$

TCLP

TTT

WAPS

WASRD

WCP

WQR

WVDP

WVNS
Glass Transition Temperature

Toxicity Characteristic Leaching Procedure

Time-Temperature-Transformation

Waste Acceptance Product Specifications

Waste Acceptance System Requirements Document

Waste Form Compliance Plan

Waste Form Qualification Report

West Valley Demonstration Project

West Valley Nuclear Services 


\section{Preliminary Waste Form Compliance Plan for the Idaho National Engineering and Environmental Laboratory High-Level Waste}

\section{INTRODUCTION}

In 1993, the Department of Energy-Office of Civilian Radioactive Waste Management (DOE-RW) published the Waste Acceptance System Requirements Document (WASRD) describing the system-level requirements for spent nuclear fuel (SNF) and high-level waste (HLW) to be accepted for emplacement in a federal licensed repository. The DOE-Office of Environmental Management (DOE-EM) developed Waste Acceptance Product Specifications (WAPS), also published in 1993, defining specific technical and documentation requirements for vitrified HLW forms to satisfy the higher-level requirements of the WASRD. The WAPS is divided into five sections: (1) Waste Form Specifications, (2) Canister Specifications, (3) Canistered Waste Form Specifications, (4) Quality Assurance Specifications, and (5) Documentation and Other Requirements. The WASRD requires the waste form producer to document compliance with the WAPS in the following four documents or sets of documents: (1) Waste Form Compliance Plan (WCP), (2) Waste Form Qualification Report (WQR), (3) production records, and (4) storage and shipping records.

- The WCP describes the waste in storage, the process for preparing the waste for emplacement in a federally licensed geologic repository, and the proposed methods and strategies by which the waste form producer will demonstrate compliance with each specification of the WAPS. The WCP also forms the basis for the more detailed WQR.

- The WQR reports the results of tests and analyses described in the WCP. Results reported in the WQR demonstrate that the selected process reliably produces waste forms that are acceptable for emplacement in a federally licensed geologic repository.

- Production records include the documentation needed to demonstrate the acceptability of individual as-produced waste forms for emplacement in a federally licensed geologic repository. Any characteristics of a waste form failing to meet specifications would be identified as a nonconformance in the production records. Resolutions will be developed with input from DOE-Idaho Operations Office (DOE-ID) and DOE-RW.

- Storage and shipping records include the documentation necessary to demonstrate that waste forms have been properly stored after fabrication and are ready for shipment to the repository. Storage conditions are selected to ensure that the waste forms are not altered after production and to maintain the identities of individual waste forms.

Idaho Nuclear Technology and Engineering Center. The DOE processed SNF at the Idaho Nuclear Technology and Engineering Center (INTEC) from 1953 to 1992 . Acidic high-level liquid waste (HLLW) from the reprocessing operation was accumulated in stainless steel tanks and periodically converted to a solid form by a thermal process called calcination. The resulting granular high-level solid waste, called calcine, is stored in shielded underground storage bins at the Idaho National Engineering and Environmental Laboratory (INEEL) Calcined Solids Storage Facilities (CSSF). Currently, $3800 \mathrm{~m}^{3}$ of calcine is in storage in six CSSF. In addition, 6.8 million liters of radioactive liquid waste is stored in the ICPP Tank Farm. 
About 5.7 million liters of the radioactive liquid waste stored in the Tank Farm is sodium-bearing liquid waste from decontamination activities. The sodium-bearing waste is difficult to calcine because the high sodium content causes the fluidized bed of the calciner to agglomerate. Thus processing alternatives are being considered for the immobilization of the stored sodium bearing waste.

Recommended Treatment Process. The process for immobilizing HLW at the INEEL has not yet been finalized. A detailed systems analysis, conducted in 1994, recommended that if HLW from INTEC is to be immobilized at the INEEL, then a two-phased approach in which the high activity fraction is vitrified and the low activity fraction is grouted is the preferred option ${ }^{(1)}$.

The two-phased approach for HLW immobilization, is illustrated in Figure 1. First, calcine would be dissolved, then with remaining liquid wastes, subjected to a separations process. This second phase would produce a diminished volume of high activity waste (HAW) to be vitrified either on site or at an off site facility, and a volume of low activity waste (LAW) to be grouted. This Preliminary Waste Form Compliance Plan has been prepared in the event that this approach will be approved by DOE for implementation at the INEEL.

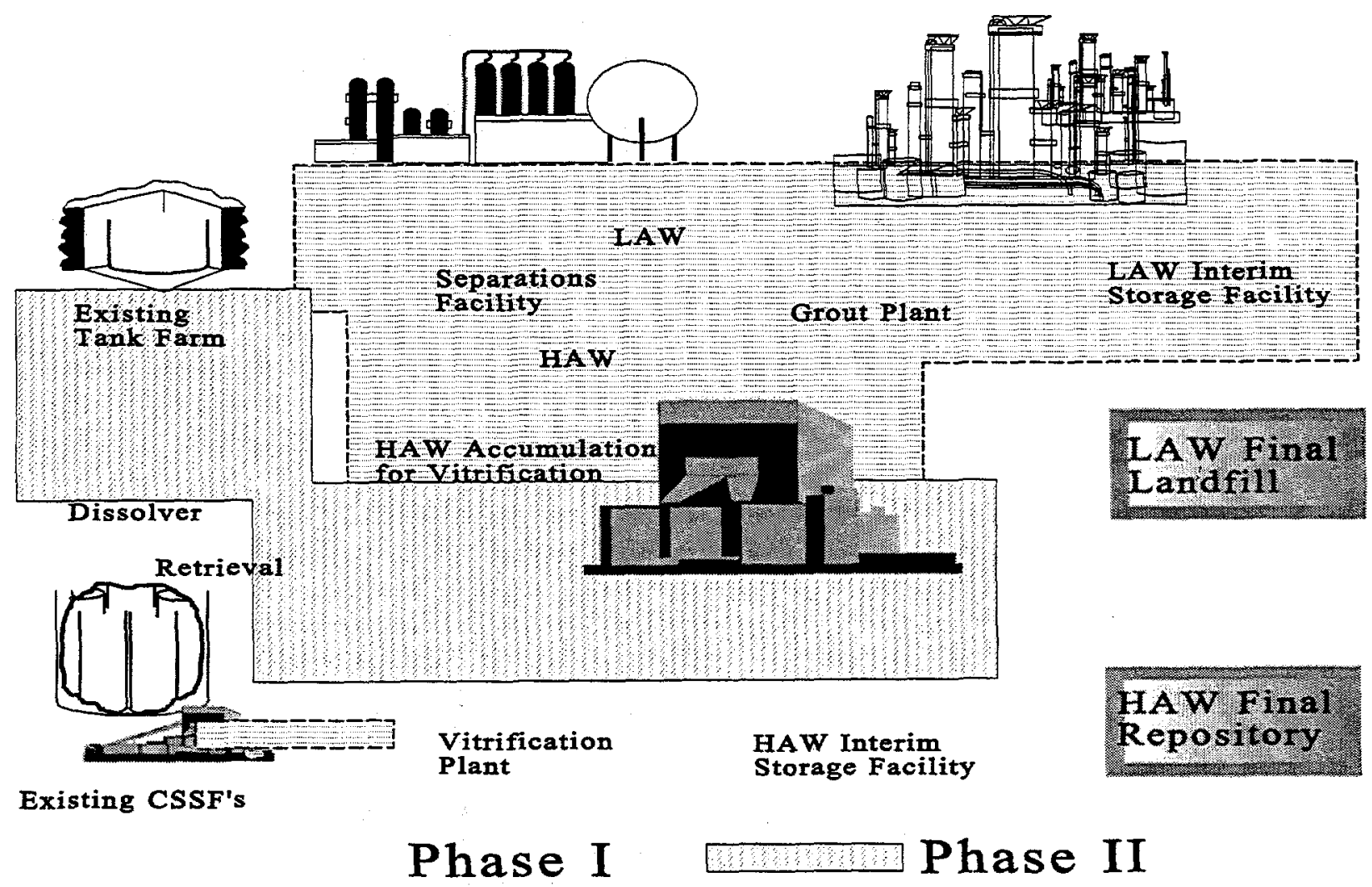

Figure 1. Recommended HLW immobilization approach.

Assumptions. Many of the technical details associated with the recommended approach have not yet been developed. In particular, neither the separations nor the vitrification processes have been fully developed. Consequently, the nature of the HAW is not yet fully defined. As a result, details concerning process equipment and control system design and the formulation of the final waste form are not available. Where necessary, assumptions have been made (as listed below) to provide details needed to prepare this Preliminary Waste Form Compliance Plan (PWCP). Supporting data have been compiled 
from currently (June 1995) available estimates. The technology selection process, when completed, may render many of these assumptions unnecessary or invalid.

- DOE will adopt the recommended preferred option ${ }^{(1)}$ for immobilization of INEEL HLW.

- Borosilicate glass will be the host for immobilizing INEEL HLW.

- $\quad$ All HAW from the separations process (from treatment of both sodium-bearing waste and dissolved calcine) will be accumulated in a single tank to simplify cold make-up and analytical activities associated with the vitrification process.

- Vitrification will not begin until all separations operations are completed to ensure a constant feed composition for vitrification, thereby simplifying cold make-up and analytical activities associated with the vitrification process.

- A single waste stream will feed the INEEL vitrification process, producing a single waste type. This assumption is based on the previous two assumptions.

- HAW and chemical additives will be blended batch-wise in a small tank for delivery to the melter. This blending tank will be a key process control point.

- The Defense Waste Processing Facility (DWPF) and West Valley Demonstration Project (WVDP) began radioactive operations in 1996. The canister selected for use with the INEEL vitrification process will be the more compatible of the two with that process. Adopting a certified waste glass production canister design and associated process steps will reduce costs affiliated with qualifying the canister.

NOTE: Canister qualification is part of implementing a vitrification process and therefore contributes to the overall cost. Without canisters the process cannot operate.

Overview of the Preliminary Waste Form Compliance Plan. The PWCP is the first step towards preparing a formal WCP for immobilizing HLW at the INEEL. This PWCP was prepared, if needed, to describe development efforts and to provide a starting point for development of the final WCP for INEEL HLW. Because of the technical uncertainties associated with an ongoing development program, the PWCP lacks the details that will be expected in a final WCP. The PWCP can be revised periodically to reflect progress in the development program until sufficient details are available to prepare a formal revision of the WCP.

Accordingly, compliance strategies and technologies described in the WCPs for DWPF and WVDP have been adopted in this PWCP wherever appropriate, thereby identifying opportunities for technical interaction between the sites. Subsequent revisions of the PWCP will reflect developments resulting from such technical interactions.

This PWCP describes the activities being proposed to demonstrate that any vitrified waste form produced by the recommended process for immobilizing INEEL HLW complies with the WAPS requirements ${ }^{(2)}$. Each specification from the WAPS appears in italics and is followed by a description of the INEEL's compliance strategy. In most cases, compliance will be demonstrated through a combination of component specifications and process controls. A more detailed implementation plan follows the compliance strategy. Research and development $(R \& D)$ activities and testing programs needed to qualify the waste form are described under the implementation sections. The documentation required to demonstrate compliance with each specification is also described. 
With the exception of Section 5.0, this PWCP adopted the specification numbering system from the WAPS to provide a one-to-one correspondence between specifications and compliance plans. Most waste acceptance documentation requirements (corresponding to WAPS, Section 5.1) are included with the specification from which they are derived. Other requirements, specified in WAPS Sections 5.2 to 5.14, are administrative requirements (e.g., Section 5.4, Specification for DOE Observation at Time of

Shipment, and Section 5.10, Specification for Fee Payment) and are specifically exempted from inclusion in the $\mathrm{WCP}^{(2)}$. 


\section{WASTE FORM SPECIFICATIONS}

\subsection{Chemical Specification}

The waste form is borosilicate waste glass.

\subsubsection{Chemical Composition Projections}

In the WQR, the producer shall project the chemical composition, identify crystalline phases expected to be present, and project the amount of each crystalline phase, for each waste type. The method to obtain the required data shall be described by the producer in the WCP. The data shall be provided in the WQR. Waste form compositions not available for reporting in the initial WQR shall be included in an addendum to the WQR.

COMPLIANCE STRATEGY. HLW currently stored at the INEEL will be subjected to separations processes that will concentrate radionuclides into HAW; the HAW will be accumulated in a tank for homogenization prior to startup of the vitrification process. Process flowsheets and run data from the separations processes will provide a preliminary estimate of the composition of the waste accumulated in the storage tank. Tank contents will be sampled and analyzed following separations operations and after sufficient time has elapsed to permit thorough mixing of tank contents. This information will serve as reference data for vitrification.

The INEEL will develop a computer model of the vitrification process that will project glass composition based on knowledge of feed composition. The computer model will be validated by an extensive series of pilot- and full-scale cold tests that bound the target glass composition. These studies will be reported and analyzed in the WQR. The INEEL will vitrify a single waste type containing all of the HLW constituents into a single target glass composition.

Canistered glass cooling rates will be determined based on experience of DWPF and WVDP and on prototypic, full-scale tests. Glasses that bound the potential target glass composition region will be fabricated and heat treated using the cooling rate profile. The heat treated glasses will then be characterized to determine the quantity and composition of the crystalline phases present.

MMPLEMENTATION. The INEEL will vitrify a single waste type containing all HAW constituents, thus producing a glass with one target composition selected from a range of compositions with acceptable performance characteristics. The range of waste glass compositions exhibiting acceptable performance will be empirically determined by a series of statistically designed experiments. This range is expected to be much greater than process variations resulting from both normal operating conditions and upset conditions. The actual range of process variations will be demonstrated in pilot- and full-scale tests.

The anticipated crystalline phases present in the product glass will be estimated using laboratory generated glasses exposed to heat-treatments bounding the full-scale system. Canister cooling behavior will be measured in full-scale tests and glass samples will be taken to analyze for crystalline phases. Laboratory glasses will then be exposed to the thermal history measured in the full-scale canisters to generate more complete crystalline phase data.

To characterize the crystallization behavior of actual waste glasses, target glass will be exposed to the bounding heat-treatment. Crystalline phase data, collected from both laboratory scale and full-scale tests, and data justifying the use of laboratory produced glasses will be presented in the WQR. These characterization tests will be confirmed with at least one application to radioactive glasses. 
The WQR will also discuss the effects of decay heat generation and glass production rates on the glass cooling history. The effects of decay heat will be estimated from Time-Temperature-

Transformation (TTT) diagrams (see Section 1.4.1) and discussed in the WQR. The effects of the glass filling rate for a canister on the non-vitreous phases in the product glass will also be addressed in the WQR. This assessment will determine the sensitivity of the canistered glass cooling rates to filling rates, periodic filling cycles, and anticipated glass production rates.

Cooling data for canistered glass will be collected during dedicated, full-scale tests using instrumented canisters. The temperature data will be used to determine a bounding thermal history for use in laboratory testing. Samples of glass from near the thermocouple locations will be analyzed to determine the nature and amounts of crystalline phases present. These results will be compared to results from laboratory glasses heat-treated to simulate the cooling history of full-scale glasses, and the outcome will be reported in the WQR. The crystalline content of heat-treated glass samples will be characterized by X-ray diffraction, optical microscopy, and scanning electron microscopy and transmission electron microscopy. The range of crystalline content expected in a canistered waste form will be defined from experimental results. The range will be a function of such parameters as cooling rate, glass volume, waste composition, and radial position within the canister.

DOCUMENTATION. The WQR will contain the target glass composition, an estimate of the range of glass composition and an estimate of the composition and amount of the crystalline phases to be anticipated in the canistered glass.

\subsubsection{Chemical Composition During Production}

In the Production Records, the producer shall report the oxide composition of the waste form. The reported composition shall include all elements, excluding oxygen, present in concentrations greater than 0.5 percent by weight of the glass, for each waste type. The producer shall describe the method to be used for compliance in the WCP. An estimate of the error of the reported composition and the basis for the estimate shall be reported in the WQR.

COMPLIANCE STRATEGY. Documentation of the production glass composition will be obtained from chemical analyses of glass samples obtained during production. Results of the glass sample analyses will be reported in the Production Records.

IMPLEMENTATION. The INEEL will vitrify a single HLW composition containing all of the HLW constituents, thus producing a glass with one target composition. However, waste will not be fed to the process on a continuous basis. Waste will be delivered to a make-up tank in batches, and cold chemicals will be mixed with the waste to prepare it for vitrification. Control of glass composition will be accomplished by analyzing and adjusting the contents of the make-up tank until the mixture is within a composition range that will result in an acceptable product. The target feed composition range and melter operating parameters that produce an acceptable glass will be determined during pilot- and full-scale tests.

Glass samples will be obtained from randomly selected canisters during production. The sampling method will depend on process design details, and, therefore, will not be finalized until conceptual design; the sampling method will be discussed in subsequent revisions to the WCP. Results from chemical analyses of glass samples will be reported in the Production Records.

DOCUMENTATION. The WQR will discuss the methods used to analyze elements present in the production glass in concentrations greater than 0.5 weight percent. Estimates of uncertainties and the detailed compliance strategy, including the method for selecting specific canisters for sampling, will also be described in the WQR. The Production Records will contain all glass chemical analyses for all 
elements greater than 0.5 weight percent. The overall composition of the waste type will be reported in the Production Records as an average of the individual analyses.

\subsection{Radionuclide Inventory Specification}

The producer shall report the inventory of radionuclides (in curies) that have half-lives greater than 10 years and that are, or will be, present in concentrations greater than 0.05 percent of the total radioactive inventory for each waste type, indexed to the years 2015 and 3115.

\subsubsection{Radionuclide Inventory Projections}

The producer shall provide in the WQR estimates of the total quantities of individual radionuclides to be shipped to the repository, for each waste type. The producer shall also report the upper limit of these radionuclides for any canistered waste form, and an average calculated radionuclide inventory per canister for each waste type. The method to be used to obtain the required data shall be described by the producer in the WCP. The data shall be provided in the WQR. Radionuclide inventory estimates not available for reporting in the initial WQR shall be included in an addendum to the WQR.

COMPLIANCE STRATEGY. The estimated total quantities of individual radionuclides will be based on ongoing waste characterization programs for INEEL HLW. The average estimated inventory in the canisters will be based on filling canisters 85 percent full and will account for radionuclide ingrowth. Although the year 2015 is specified in the WAPS, glass production at the INEEL may not commence until after that date.

Upper limits per canister will be based on a canister 100 percent full. Upper limits of error will be derived from analysis of the original HAW production data at the INEEL and actual HAW sample analyses.

IMPLEMENTATION. The estimated total quantities in 1996 of individual radionuclides in all calcines are based on an ongoing HLW characterization program being performed at the INEEL and are shown in Table 1-1. Certain radionuclides, including Tc-99, I-129 and Cs-135 are omitted from the table because a lack of data exists with respect to their quantities in the calcines. Computer simulations have been run using the ORIGEN2 computer code and available data from each of the waste generating irradiated fuel campaigns. Radiochemical uncertainties will be based on sample analyses. 
Table 1-1. Estimated total quantities of radionuclides with half lifes greater than 10 grams $^{2}$.

\begin{tabular}{lcc}
\hline Radionuclide & Half-life (yrs) & 1996 Total Curies \\
\hline Sr-90 & $2.88 \mathrm{e}+01$ & $1.8 \mathrm{e}+06$ \\
Cs-134 & $2.06 \mathrm{e}+00$ & $8.8 \mathrm{e}-13$ \\
Cs-137 & $3.01 \mathrm{e}+01$ & $2.2 \mathrm{e}+06$ \\
Pm-147 & $2.62 \mathrm{e}+00$ & $2.5 \mathrm{e}-09$ \\
Th-230 & $7.54 \mathrm{e}+05$ & $9.9 \mathrm{e}-02$ \\
Th-232 & $1.40 \mathrm{e}+10$ & $2.1 \mathrm{e}-07$ \\
$\mathrm{U}-233$ & $1.59 \mathrm{e}+05$ & $3.5 \mathrm{e}+00$ \\
$\mathrm{U}-234$ & $2.46 \mathrm{e}+05$ & $8.6 \mathrm{e}-01$ \\
$\mathrm{U}-235$ & $7.04 \mathrm{e}+08$ & $5.0 \mathrm{e}-01$ \\
$\mathrm{U}-236$ & $2.34 \mathrm{e}+07$ & $1.1 \mathrm{e}-00$ \\
$\mathrm{U}-238$ & $4.47 \mathrm{e}+09$ & $2.8 \mathrm{e}-02$ \\
Np-237 & $2.14 \mathrm{e}+06$ & $6.9 \mathrm{e}+02$ \\
Pu-238 & $8.77 \mathrm{e}+01$ & $3.1 \mathrm{e}+04$ \\
Pu-239 & $2.41 \mathrm{e}+04$ & $3.6 \mathrm{e}+03$ \\
Pu-240 & $6.56 \mathrm{e}+03$ & $1.5 \mathrm{e}+03$ \\
Pu-242 & $3.73 \mathrm{e}+05$ & $7.5 \mathrm{e}-00$ \\
Am-241 & $4.32 \mathrm{e}+02$ & $1.3 \mathrm{e}+03$ \\
Am-243 & $7.37 \mathrm{e}+03$ & $2.7 \mathrm{e}+01$ \\
a. Short-lived equilibrium daughters not included. & & \\
\hline & & \\
\hline & & \\
\hline & & \\
\hline & & \\
\hline & & \\
\hline
\end{tabular}

Samples will be taken at the separation tank and reported in the WQR. Projections of the estimated total quantities of individual radionuclides, based on inventories (estimated from waste characterization work) expected to be shipped from the INEEL and on corresponding individual canister inventories, will be reported in the WQR. The WAPS refers to total radioactive inventory; since under the assumptions used in developing this plan the INEEL will have only one waste type that will be accumulated in the HAW storage tank. Thus this tank is the appropriate place to sample. The average expected inventory in a canister will be based on a canister 85 percent full (see Section 3.5). The lower bound will be based on a canister 80 percent full and on lower uncertainty estimates for the total expected inventory in the waste. The upper bound will be based on a canister 100 percent full and on upper estimates for the total expected inventory in the waste.

To ensure that radionuclide reporting requirements are satisfied, the curies of radioactivity of each nuclide will be used as input to the ORIGEN2 computer code. Decay of radionuclides and ingrowth buildup of daughter nuclides in the canister will then be calculated for the years 2015 and 3115 .

DOCUMENTATION. The WQR will provide estimates of the total quantities of individual radionuclides expected to be shipped from the INEEL and the projected upper limit and average radionuclide inventory in each canister. The uncertainties of these estimates will also be reported. 


\subsubsection{Radionuclide Inventory During Production}

The producer shall provide in the Production Records estimates of the inventories of individual reportable radionuclides for each canister and for each waste type. The producer shall also report the estimated error of these estimates in the WQR.

COMPLIANCE STRATEGY. West Valley Nuclear Services (WVNS) plans to meet the WAPS requirement solely with glass shards removed from the top of the canistered glass. The inventory of key radionuclides will be measured and related to the other required radionuclide values through the use of scaling factors derived from the WVDP waste characterization program. Sampling frequency, precision, and accuracy will be based on the results of qualification testing. The glass shards will be demonstrated to be representative of the canister glass in the WQR. A similar approach for determining radionuclide inventory could be applied at the INEEL.

The WQR will include a list of all radionuclides to be shipped with half-lives greater than 10 years and that are, or will be, present in concentrations greater than 0.01 percent of the total radioactive inventory for each waste type, indexed to the years 2015 and 3115.

IMPLEMENTATION. A sampling approach similar to the one used to provide chemical composition during waste vitrification will be used to provide key radionuclide inventory in the canistered waste forms. Glass shards from a statistically random sampling of glass canisters will be analyzed for key radionuclides and related to the inventory in the canistered waste form, as discussed in Section 1.1.2. The sampling frequency and expected accuracy will be reported in the WQR. ORIGEN2 code will be used to estimate individual radionuclide contents out to 1100 years to determine which radionuclides have halflives of more than 10 years and will comprise more than 0.05 percent of total waste as measured in curies. These radionuclides are listed in Table 1-2. Radionuclide content will not be determined by wet chemistry, however, the statistical basis for the sampling strategy will be similar to that used for wet chemical sampling. In the WQR, radionuclides down to 0.01 percent will be identified to allow for the uncertainty in ORIGEN2 calculations and to ensure that all radionuclides down to 0.05 percent are identified. Radionuclides in the vitrification feed with half lives greater than 10 years and in concentrations greater than 0.05 percent of total radioactive inventory up to the year 3115 must be reported, per Specification 1.2.

Table 1-2. Possible radionuclide content of waste.

\begin{tabular}{lllll}
\hline Ni-59 & Tc-99 & Sm-151 & Np-236 & Pu-241 \\
Ni-63 & Pd-107 & Ac-227 & Np-237 & Am-241 \\
Sr-90 & Sn-126 & Pa-231 & Pu-238 & Am-242m \\
Zr-93 & Cs-135 & U-233 & Pu-239 & Am-243 \\
Nb-93m & Cs-137 & U-234 & Pu-240 & \\
\hline
\end{tabular}

Inventory values for those radionuclides not directly analyzed will be obtained using scaling factors. The scaling factors are ratios between the measured radionuclide isotopes and others that must be reported. These scaling factors will be based on analyses of INEEL waste samples removed after the separations process. 
Three methods are being planned to estimate the level of reportable radionuclides in the canisters. This is due to the fact that some radionuclides can be readily compared with Sr-90 and Cs-137 and others cannot. For instance, since most uranium isotopes were recovered as products from chemical separations, shipping records and waste measurement values are used for these radionuclides.

The simplest method will be used for Cs-137. This radionuclide, with its short-lived daughter, represents nearly half of the total activity in the glass (circa 1996). Therefore, it can be measured directly. Samples from a subset of the entire set of canisters will be analyzed for these radionuclides, and the mean and standard deviations reported. ORIGEN2 decay calculations will be applied to the data, and the predicted concentrations for the years 2015 and 3115 reported.

A second method will be used for determining other reportable radionuclides including: Np-236, $\mathrm{Np}-237$, Pu-238, Pu-239, Pu-241, Am-241, Am-242m, and Am-243. Based on the radioanalysis of waste samples before vitrification, the ratios of these radionuclides will be computed relative to the amount of $\mathrm{Sr}-90$ in the waste. From these ratios and the measured Sr-90 levels in the glass filled canisters (and their uncertainties), the levels and uncertainties of this set of radionuclides will be computed. Since these radionuclides are present in much smaller levels compared to $\mathrm{Sr}-90$, the uncertainties for them are expected to be over 100 percent relative.

A similar approach will be used for Tc-99. During waste processing prior to vitrification, most if not all of the Tc-99 will be contained in the low-level waste (LLW) cement waste form. After waste processing has been completed and before the start of vitrification, the ratio of Tc-99 relative to Cs-137 will be measured. Based on this ratio and the measurement of Cs-137 in the glass-filled canisters, the level of Tc-99 and its uncertainty will be computed. The projected level of Tc-99 to be characterized after all LLW processing is completed is less than $0.1 \mathrm{pCi} / \mathrm{ml}$ of solution. Since Tc-99 is present in much smaller levels compared to Cs-137 and is close to the detection limit, the uncertainty in the ratio is expected to be over 100 percent relative.

This same type of approach will be used for Cs-135. Using Cs-137 as the key measurement, the level and uncertainty of Cs-135 will be computed based on analyses of waste samples removed after separations.

Total canister radionuclide inventory for production canisters will be determined by applying the concentrations determined from the above analyses to the actual measured glass content (i.e., fill height) of each canister.

Calculated uncertainties for radionuclides sampled and analyzed will be reported in the WQR. Uncertainties for other radionuclides will be determined using error propagation to combine uncertainties in measured values and ratios.

DOCUMENTATION. The WQR will detail all reportable radionuclides with half-lives greater than 10 years and that are, or will be, present in concentrations greater than 0.01 percent indexed to years 2015 and 3115 . The WQR will also detail the methods to be used to determine the radionuclide inventory during production and the precision and accuracy of the methods used. The mean and standard deviations will be computed and reported on a total production campaign basis.

The Production Record for each canistered waste form will include estimates of the content of each reportable radionuclide, based on analysis of the shards and computed across the entire production campaign. The values reported in the Production Records will either be measured or calculated values, depending on the particular radionuclide and will be noted as such. 


\subsection{Specification for Product Consistency}

The producer shall demonstrate control of waste form production by comparing, either directly or indirectly, production samples to the Environmental Assessment (EA) benchmark glass ${ }^{(3)}$. The producer shall describe the method for demonstrating compliance in the WCP and shall provide verification in the Production Records. The producer shall demonstrate the ability to comply with the specification in the $W Q R$.

\subsubsection{Acceptance Criterion}

The consistency of the waste form shall be demonstrated using the Product Consistency Test $(\mathrm{PCT})^{(4)}$. For acceptance, the mean concentrations of lithium, sodium, and boron in the leachate, after normalizing for the concentrations in the glass, shall each be less than those of the benchmark glass described in the EA for selection of the DWPF waste form (U.S. DOE 1982). The measured or projected mean PCT results for lithium, sodium, and boron shall be provided in the Production Records. The producer shall define the statistical significance of the reported data in the WQR. One acceptable method for demonstrating that acceptance criterion is met would be to ensure that the mean PCT results for each waste type are at least two standard deviations below the mean PCT results of the EA glass.

\subsubsection{Method of Compliance}

The capability of the waste form to meet this specification shall be derived from production glass samples and/or process control information.

Production Records shall contain data derived from production samples, or process control information used for verification, separately or in combination. When using process control information to project PCT results, the producer shall demonstrate in the WQR that the method used will provide information equivalent to the testing of samples of actual production glass.

COMPLIANCE STRATEGY. The INEEL will predict waste glass PCT results, based on the composition of the melter feed and on an analysis of random samples of production glass, and compare these predictions to measured EA glass data. The PCT predictions will be based on a regression model that correlates measured PCT results to waste glass composition and, if appropriate, any other process parameters. For the radioactive production glass, the reported PCT predictions will be validated by analyzing random samples of production glass. The predicted normalized $\mathrm{PCT}$ releases for $\mathrm{Li}, \mathrm{Na}$, and $\mathrm{B}$ will be compared to available data from the benchmark EA glass to demonstrate compliance with this specification.

PCT results are primarily determined by the composition of the waste glass. Melter feed composition provides almost exclusive control of waste glass composition. Feed composition data and the projected glass composition will be translated into predicted PCT results by an empirical model. Before releasing any feed batch for processing, the ability of that batch to produce acceptable glass as defined by the specification will be verified. This procedure will be embedded in the Process Control Program (PCP), and a detailed description of the procedure will be included in the PCP support documentation.

IMPLEMENTATION. A mathematical model will be used to predict PCT results for INEEL waste glass to compare with PCT results from the EA standard. PCT data on the EA standard glass will be obtained from other laboratories that participated in certification of the material. The model will be developed using results from laboratory-, pilot-, and full-scale testing of the vitrification process. 
Laboratory testing will be performed using both simulated (non-radioactive) and actual (radioactive) waste. Statistically designed experiments will be used first to identify processing parameters that have a statistically significant effect on product performance (as measured by the PCT), and then to map product performance onto the defined parameter space. These tests will also establish the accuracy of results obtained from simulated waste forms by allowing direct comparison with actual waste forms on a laboratory scale. Results from laboratory testing will be used to develop the initial version of the model.

Pilot-scale tests will be performed with simulated waste to minimize pilot plant costs and to avoid the risks associated with production of large quantities of radioactive experimental glass. Pilot-scale testing will be performed to observe any influence of scale-up on the model. Testing will also provide statistical information related to process stability, thereby providing the information needed to implement the control strategy necessary to achieve acceptable product consistency.

Full-scale (startup) testing of the vitrification process will use statistically designed experiments to explore the full range of significant process control parameters and their influence on product performance. This stage of testing will be used to verify the mathematical model used to predict product performance and to determine the uncertainty associated with the model. Initial full-scale testing will be performed with simulated waste and will lead to qualification testing and radioactive operation.

The mathematical model will be incorporated into a computer program to monitor and control the vitrification process. Input to the PCP will include all process parameters that can be shown to have a statistically significant effect on PCT results. While feed composition is the process control parameter that most directly influences PCT results, other process parameters, such as melt temperature and residence time, can also have an effect. These other parameters will be monitored and controlled within specific limits to produce a consistent product. In addition to predicting PCT results, the PCP will archive process control data and use methods of statistical process control to provide additional assurance of product consistency. During full-scale tests and operation with actual waste, glass will be sampled on a random basis to verify results obtained from the PCP.

DOCUMENTATION. The WQR will contain data required for demonstrating compliance to the product consistency specification. Such data will include details regarding composition and PCT models, EA glass PCT data, methods of comparing them to the production glass data, methods of sampling the production glass, and identification of the glass samples used for analysis. Production Record contents will be detailed in the WQR, and will include data on chemical analyses of glass samples, comparison to the EA value, predicted PCT results for each of the glass samples, the mean of these predicted PCT results, and the accuracy of the results. Verification that the production glass is in compliance with this specification will be included in the Production Records.

\subsection{Specification for Phase Stability}

\subsubsection{Phase Stability Information}

The producer shall provide the following data for each projected waste type:

(a) the glass transition temperature; and

(b) a TTT diagram that identifies the duration of exposure at any temperature that causes significant changes in either the phase structure or the phase compositions.

The method to be used to obtain the required data shall be described in the WCP. The data itself shall be provided in the WQR. 


\subsubsection{Control of Temperature for Phase Stability}

At the time of shipment, the producer shall certify that after the initial cool-down, the waste form temperature has not exceeded $400^{\circ} \mathrm{C}$. The producer shall describe the method of compliance in the WCP.

COMPLIANCE STRATEGY. The glass transition temperature of the target glass composition for immobilizing INEEL HLW will be determined using standard methods. A TTT diagram will also be developed for the target glass composition.

The heat generation from radioactive decay is expected to be insufficient to produce or maintain glass centerline temperatures above $400^{\circ} \mathrm{C}$ after the initial cooling period. The INEEL interim storage facility will be designed to maintain glass centerline temperature below $400^{\circ} \mathrm{C}$ using active and/or passive measures.

IMPLEMENTATION. The glass transition temperature $\left(\mathrm{T}_{\mathrm{g}}\right)$ will be measured by dilatometry or differential scanning calorimetry using standard methods. Dilatometry detects the glass transition temperature as the sharp change in slope in the plot of thermal expansion versus temperature that occurs at $T_{\mathrm{g}}$. Differential scanning calorimetry shows an exothermic shift of the baseline at $\mathrm{T}_{\mathrm{g}}$.

The glass transition temperature of the target glass composition will be measured, and the effect of variations in glass composition on $\mathrm{T}_{\mathrm{g}}$ will be determined from measurements on glass samples produced during development of the $\mathrm{PCP}$ (see Section 1.3). These data are expected to show little variation of $\mathrm{T}_{\mathrm{g}}$ with respect to variations of glass composition anticipated during production. These data will be reported in the WQR.

A TTT diagram illustrates the devitrification (crystallization) behavior of a glass in response to isothermal heat treatments for various lengths of time. The TTT diagrams will be obtained from glasses of the target composition produced using simulated waste during laboratory-, pilot-, and full-scale testing. An estimate of scale-up effects, such as nucleation initiated by contaminants from refractory wear, can be obtained by comparing these data. TTT diagrams will cover the temperature range from $T_{\mathrm{g}}$ to the temperature. Heat treatment times will range from 0.5 hour to 48 hours. The anticipated maximum canister centerline temperature will be well below $400^{\circ} \mathrm{C} 48$ hours after canister filling is completed. Crystalline phases resulting from heat treatments will be identified, and the volume fractions occupied by the crystalline phases will be estimated using standard methods, such as X-ray diffraction, optical microscopy coupled with image analysis, and electron microscopy. These data will be reported in the WQR.

The maximum glass temperature between initial cool-down and shipment to the repository will be estimated by computer modeling. The computer model will take into account radionuclide loading (as a heat source), glass and canister physical properties, and heat transfer characteristics of the interim storage facility. The heat generation rate from radioactive decay will be estimated using the latest version of ORIGEN2 or an equivalent program incorporating radionuclide inventory data. Physical properties of the waste glass, including thermal conductivity and heat capacity, will be measured on experimental glass of the target composition prepared using simulated waste. Physical properties of the canister will be obtained from published data. Heat transfer characteristics of the interim storage facility will be calculated from design data and anticipated operating conditions. A temperature monitoring system will be installed in the interim storage facility to verify the results of these calculations and to provide a record of storage conditions. 
DOCUMENTATION. The WQR will document the $\mathrm{T}_{\mathrm{g}}$ and the TTT diagram for the target glass composition. The WQR will also detail the experimental methods used to produce the data and discuss expected variations in the reported data. Calculations used to predict glass temperature during interim storage will also be described.

The Storage and Shipping Records for each canistered waste form will include the calculated thermal history after initial cool-down for each canister to demonstrate that the maximum allowable temperature of $400^{\circ} \mathrm{C}$ was never exceeded. The Storage and Shipping Records will also report the portion of the temperature record from the interim storage facility temperature monitoring system that corresponds to the time period that the canister was in storage. Any event that may have caused the temperature of the glass to exceed $400^{\circ} \mathrm{C}$ at any time between initial cool-down and shipment will be described in the Production or Storage and Shipping Records, depending on when the event occurred. If the event occurs before the canister is placed in the interim storage facility, it will be reported in the Production Records. Events occurring after the canister is placed in interim storage will be reported in the Storage and Shipping Records. The maximum temperature reached by the glass during the event and the maximum residence time at that temperature will be calculated and reported, along with a description of the calculations performed. Any canister exposed to such an event will be handled as a non-conforming item.

\subsection{Hazardous Waste Specification}

The producer shall report in the WQR whether the waste form proposed for storage or disposal in the Civilian Radioactive Waste Management System is hazardous listed waste [Section 40 of the Code of Federal Regulations (CFR) subparts 261.20 through 40 CFR 261.24]. If the waste form is determined to be listed hazardous waste the quantity of listed waste introduced into the waste form from the feed stream shall be reported in the WQR.

The producer shall perform the "Toxicity Characteristic Leaching Procedure" $(T C L P)^{(S)}$ and other Resource Conservation and Recovery Act (RCRA) characteristic tests ${ }^{(6)}$, as appropriate, using prototypical specimens of the projected bounding glass compositions to determine if the waste form is characteristic hazardous waste. The method to be used must be described in the WCP and the results documented in the WQR.

If the canistered waste forms are determined to be hazardous, the producer shall include a "Hazardous Waste Manifest" in the Production Records.

COMPLIANCE STRATEGY. Listed hazardous wastes have been discharged into the ICPP Tank Farm $^{(7)}$. Because a repository may not accept listed or characteristic wastes, the INEEL most initially inventigate:

- treatment options to remove hazardous materials from the waste to be vitrified, and

- regulatory options to remove hazardous waste codes from the vitrified waste form.

In either case, the vitrified waste form will be shown not to be a characteristic hazardous waste by performing the TCLP on a range of glass compositions bounding the composition range anticipated for production glass. Selection of a compliance strategy from these two options will be performed after the INEEL immobilization process is more completely developed. 
IMPLEMENTATION. The INEEL will first apply for a treatability variance for the glass waste form. A treatability variance will eliminate many of the waste codes that would presently be associated with the glass waste form from further consideration. A petition(s) will then be filed to delist the remaining waste codes. If this approach is unsuccessful, the quantities of listed wastes potentially introduced into the waste form will be identified from a previous study ${ }^{(7)}$. A copy of the report from this study will be included in the WQR. Analyses will be performed to verify the presence of the suspected hazardous waste associated with the waste codes in the glass waste form. If the hazardous waste cannot be detected in the glass waste form, regulators will be petitioned to reclassify the waste.

The INEEL's glass waste form must be shown not to posses any attributes that would cause it to be classified as a characteristic hazardous waste. A characteristic waste must exhibit one or more of the following attributes: corrosivity, ignitability, reactivity, or toxicity. Glass is neither corrosive, ignitable, or reactive. Therefore, the glass waste form will not be considered a characteristic hazardous waste if it can be shown to be non-toxic.

The TCLP is the Environmental Protection Agency-mandated test for determining whether a waste form exhibits toxicity. Samples of INEEL waste glass that bound the composition region expected during production will be prepared with two different loadings of the hazardous elements contained in the waste. One set of samples will be prepared with the loading of hazardous elements anticipated during production, and the second set of samples will be prepared with three times the anticipated hazardous component loading. Both sets of samples will be submitted for TCLP at a certified, independent laboratory. It is highly unlikely that the glass will fail TCLP because the waste form was developed for leach resistance. During production, the INEEL will ensure that the concentration of toxic elements in the glass does not exceed the maximum concentration tested by TCLP.

DOCUMENTATION. The WQR will include a copy of the report describing the hazardous waste codes potentially attributed to INEEL HLLW. The WQR will report the results of petition efforts to delist the INEEL glass waste form. The WQR will also include the results of the TCLP testing of the doped simulated samples. 


\section{CANISTER SPECIFICATIONS}

\subsection{Material Specification}

The waste form canister, the canister label, and any secondary canister applied by the producer shall be fabricated from austenitic stainless steel. Applicable American Society for Testing and Materials $(\text { ASTM })^{(8)}$ or other nationally recognized alloy specifications and the composition of the canister materials, the canister label materials, and any filler materials used in welding shall be included in the WCP. Documentation of compliance shall be included in the Production Records.

COMPLIANCE STRATEGY. Since WVDP and Savannah River Site (SRS) will have already used different canister designs in the production of waste glass prior to operation of the INEEL's vitrification facility, it is likely that one of the designs will be suitable for the INEEL vitrification process. The most compatible of the designs will be selected for use at the INEEL, thus minimizing development costs. Confirmation that the selected canister materials comply with specifications will be provided by material test reports, analytical testing, and detailed inspection. The fabricator will provide procurement and fabrication reports documenting that certified materials were used and the heats, traceable to each canister (including the chemical analysis of the heats), at which the canister parts were fabricated. Canisters will be inspected and tested, and material conformance verified, by a quality assurance (QA) representative at the fabricating vendor.

IMPLEMENTATION. To reduce costs, the INEEL will select the compatible canister design (either the WVDP or SRS design) during conceptual design of the vitrification facility. Canisters for WVDP and DWPF vitrified wastes are fabricated from ASTM A240 (Type 304L stainless steel). Thus canisters for containing INEEL's vitrified waste will probably be fabricated from the same material. The composition of the canister material, ASTM A240, is given in Table 2-1. The composition of the weld filler metal, American Society of Mechanical Engineers (ASME) SFA5.9 ER 308L, is given in Table 2-2. The $308 \mathrm{~L}$ alloy will also be used for the canister identification labels.

The INEEL canister fabrication and equipment specification document will be incorporated into the WQR and will reference the original canister documentation generated. The fabricator will be required to use certified materials and provide certified material test reports on the heats at which the canister parts were made. In addition, the INEEL will require that the results of a second chemical analysis, performed by an independent laboratory, be provided for each metal heat used. Canisters will be inspected and material conformance verified at the fabricating vendor by an INEEL QA representative.

DOCUMENTATION. The WQR will specify the metal alloys (manufactured to ASTM or ASME specifications) to be used in canister fabrication and reference the documentation accompanying the selected canister design. The WQR will also specify the controls and inspections required to ensure that the materials are properly certified and identified. Production Records will include a certification that materials test reports for every canister and its component parts are acceptable. 
Table 2-1. Chemical composition requirements for ASTM A240 Type 304L stainless steel (S30403).

\begin{tabular}{llc} 
& Element & Percent* \\
\hline $\mathrm{C}$ & 0.03 \\
$\mathrm{Mn}$ & 2.00 \\
$\mathrm{P}$ & 0.045 \\
$\mathrm{~S}$ & 0.03 \\
$\mathrm{Si}$ & 0.75 \\
$\mathrm{Cr}$ & $18.00-20.00$ \\
$\mathrm{Ni}$ & $8.00-12.00$ \\
$\mathrm{~N}$ & 0.10 \\
\hline \multirow{2}{*}{ Maximum values unless range is indicated. } & Balance \\
\hline
\end{tabular}

Table 2-2. Chemical composition requirement of Type 308L stainless steel weld metal, ER 308L (W30843).

\begin{tabular}{lc}
\hline Element & Percent* \\
\hline $\mathrm{C}$ & 0.03 \\
$\mathrm{Cr}$ & $19.50-22.00$ \\
$\mathrm{Ni}$ & $9.00-11.00$ \\
$\mathrm{Mo}$ & 0.75 \\
$\mathrm{Mn}$ & $1.0-2.5$ \\
$\mathrm{Si}$ & $0.30-0.65$ \\
$\mathrm{P}$ & 0.03 \\
$\mathrm{~S}$ & 0.03 \\
$\mathrm{Cu}$ & 0.75 \\
$\mathrm{Fe}$ & Balance \\
\hline Single values are shown as maximum. Other elements (not shown) should not be present in excess of 0.50 percent. \\
\hline
\end{tabular}




\subsection{Fabrication and Closure Specification}

The canister fabrication and closure methods shall be identified in the WCP. The outermost closure shall be leaktight to $1 \times 10^{-4} \mathrm{~atm}-\mathrm{cc} / \mathrm{sec}$ helium. The method for demonstrating compliance shall be described by the producer in the WCP. The WQR shall provide evidence that the canister fabrication and closure methods are capable of complying with the leaktightness criterion. Compliance during production shall be documented in the Production Records.

COMPLIANCE STRATEGY. The INEEL stainless-steel canisters will be fabricated from rolled plate for the cylindrical body, the dished head, and the reverse dished bottom; pipe may be used for the flange. Canister integrity will be ensured by components specifications, fabrication specification, and a rigorous program of inspection and verification. Final, leaktight (as defined in this specification) weld closure of the canisters will be performed as soon as practical after filling and will effectively isolate the waste glass from the environment during subsequent handling and storage. The resistance of the final lid closure to leakage will be ensured at the INEEL by close control of the welding process and by weld inspection.

IMPLEMENTATION. The INEEL plans to fabricate its canister by cold rolling stainless steel plate to form the canister wall. The canister bottom will be a flanged and reverse dished head; the top will be a flanged and dished head. The lifting flange may be fabricated from pipe.

The INEEL canister fabrication or equipment specification (to be provided with the canister design and referenced in the WQR, Section 2.2) details the canister materials, the procedural protocols, and the acceptance requirements. An INEEL QA field representative will verify that canister fabrication specifications have been followed via inspections at the fabricator's shop. Fabrication welding will be according to the methods specified in the canister design selected. All fabrication welds will be inspected by dye penetrant according to Section V of the ASME Boiler and Pressure Vessel Codes and meet the criteria of Section IX. Certifications that the welds were made and inspected as specified will be required from the fabricator. Canister documentation inspection will verify that these certifications are included. After weld fabrication, the canisters will be labeled (see Section 2.3), weighed, and helium leak tested to ensure leaktightness to $0.0001 \mathrm{~atm}-\mathrm{cc} / \mathrm{sec}$ helium.

NOTE: Applicable sections of the ASME Boiler and Pressure Vessel Code are referenced for welding and nondestructive evaluation, but the canister is not classified as a code vessel.

The INEEL will perform data reviews as part of the fabrication effort to ensure that the canisters comply with design requirements. The results of weld inspections and leak testing of canisters used during cold testing will be provided in the WQR; comparable information for canisters used during HLW vitrification will be provided in the Production Records.

Canisters received by the INEEL will be subjected to inspections for damage incurred in shipping. Any canisters that are found to be damaged will be treated as nonconforming items and returned to the vendor.

Final weld closure of the INEEL canisters will be performed in the vitrification facility at the earliest practical time after filling. Canisters will be decontaminated if required, then transferred to a welding station for weld surface preparation, and welding of the lid onto the canister. Under normal process conditions, it is likely that weld closure will be performed within about two days after the canister is removed from the process. In the time period after glass filling, the INEEL process design will protect against the entry of prohibited substances into the canister. However, in the event that the filled canister must be removed from the process but cannot be directly transferred to the weld station for lid closure, 
temporary canister lid covers will be used to protect the canister contents. The INEEL will use the closure method developed and qualified for the selected canister design to seal the lid onto the canister.

Weld qualification will be evaluated via metallographic examinations, burst tests and/or tensile and bend weld zone coupon tests, and helium leak tests. Helium leak tightness measurements will be performed using the Helium Mass Spectrometer Leak Testing Method in accordance with ASME Section V, Article 10, 1989 edition, including the 1990 addenda. Tests will be performed on full-sized canisters and on dummy canister tops that duplicate the upper 18 inches of the production canister. Those parameters that produce an integral leaktight closure will form the basis for the welding procedure that will be used for the routine closure of production canisters. In-cell visual inspection of the closure welds will augment weld parameter control as a means of assessing weld quality. The ability to visually resolve pores, cracks, spatter marks, and incomplete fusion under conditions simulating those expected in-cell will be evaluated, and the relevance of visual inspection results to weld quality will be discussed in the WQR.

DOCUMENTATION. The WQR will include by reference the canister fabrication or equipment specification developed for the selected canister design. The Production Record for each canistered waste form will certify that canister components and the entire canister were fabricated according to approved drawings and procedures and meet procurement specifications. Inspection records verifying that canisters were fabricated according to specification will be included in the Production Records. The Production Record will also verify the integrity of the final closure weld made at the INEEL by reporting the critical welding process parameter values from closure operation and the visual inspection results.

\subsection{Identification and Labeling Specification}

\subsubsection{Identification and Labeling}

The producer shall assign a unique alphanumeric identifier to label each outermost canister that is produced. This label shall appear on the canistered waste form and on all documentation pertinent to that particular canistered waste form.

Each canister shall be labeled in two locations: one visible from the top and one from the side of the canister. The identification code shall be printed in a type size of at least 92 points using a sans serif type face. A proposed layout shall be provided in the WCP. Labels shall be applied to the exterior of the outermost canister and shall not cause the dimensional limits (Specification 3.11) to be exceeded.

The label shall be designed to be legible after filling and storage at the producer's facility and shipment to the repository. The label shall be an integral part of the canister and shall not impair the integrity of the canister.

COMPLIANCE STRATEGY. The code planned for identifying the canistered waste forms is a seven character alphanumeric code consisting of four letters and three numbers. The label lettering will conform to the specification. The label itself will be made of an austenitic stainless steel to assure compatibility with the canister. The reference labeling technique will be bead-welding (SS 308L) of the alphanumeric characters directly onto the canister surface (SS 304L). This labeling technique will be shown to be suitable by fabricating full-sized weld-bead labeled canisters, handling and decontaminating the labeled canister in a manner similar to that used in the INEEL process, and then establishing that the labels are still readily legible and not subject to preferential obliteration. 
IMPLEMENTATION. Each INEEL canister will have a unique identification code of the form INEEL XXX, where $\mathrm{X}$ is a digit. This identification code will appear in the Production Records that describe the canistered waste. An example of the INEEL Production Record format will be included in the WQR.

The identification code will be located on the canister in two places: on the top shoulder of the canister so that the code can be seen from the top, and on the side of the canister about $60 \mathrm{~cm}$ from the top. The characters for these labels will be between $3.25 \mathrm{~cm}$ (92 points) and $5.1 \mathrm{~cm}$ (144 points) tall and will be modified block; an example of an ideal label and the size and spacing relationships of the characters is shown in Figure 2-1. Characters will have a profile height not exceeding $0.15 \mathrm{~cm}$. The label characters will be inscribed on the canisters as weld beads using a $308 \mathrm{~L}$ austenitic stainless-steel welding rod. Since the label will be a weld bead, compatible with the canister, the service life of the label is expected to match that of the canister fabrication welds.

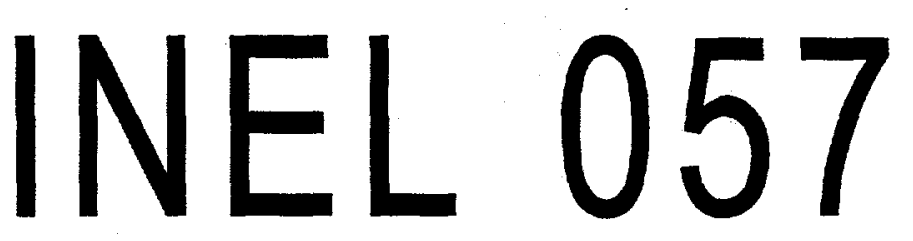

\section{$3.25 \mathrm{~cm}-5.1 \mathrm{~cm}$}

Figure 2-1. INEEL sample HLW canister label.

The unique identification code to be assigned to a canister will be provided to the fabricator by the INEEL. Canister inspection will verify that both labels on a canister are the same and that each canister's identification number is unique. The results of this inspection will be recorded in the Production Records. Additional inspections will require that the weld character height profile does not exceed $0.15 \mathrm{~cm}$ and that any defects that could trap contamination be removed before the canisters are accepted at the INEEL.

Before transfer to temporary storage, the labels on the canistered waste form will be visually inspected via a television camera or through a shielded window to ensure that the labels are intact (undamaged) and legible. This procedure will also be repeated before placing the canisters into the transportation casks. The results of this inspection will be included in the Storage and Shipping Records.

The effect of glass pouring, subsequent handling, and decontamination on the label will be evaluated and discussed in the WQR. These operations must not affect the legibility and durability of the label.

The INEEL canistered waste form storage facility will be designed to minimize potential canister and label corrosion. In this facility, normal ventilation airflow will maintain the temperature of the canister surfaces sufficiently low to minimize corrosion kinetics but high enough to prevent water condensation on the canister exterior. It is anticipated that the environment for radioactive canister interim storage at the INEEL will be benign to $308 \mathrm{~L}$ stainless steel and have little impact on label service life.

Experimental measurements performed in connection with current canister development show little evidence for localized weld bead corrosion. Microhardness scans in the base metal and in the canister weld zones reveal no brittle phases. The microhardness measurements also indicate nearly identical hardness values within the weld bead character and in the base metal. This suggests that the label is not 
any more susceptible to damage and deformation (which could affect legibility) than the canister base metal itself.

Despite precautions that will be taken during canister handling and storage operations at the INEEL, a small probability exists that both canister labels could be obliterated. To ensure that canister identity is never compromised, even in this unlikely event, the INEEL will maintain a map to identify the location of each canister in the storage facility.

DOCUMENTATION. The WQR will report on the identification code and the legibility of the label under processing and storage conditions. The labeling materials and techniques will be incorporated into the WQR via reference to the original documentation generated to qualify the selected design. The Production Records will identify each canister by its unique code. The Storage and Shipping Records will report on canister label legibility before shipment.

\subsection{Specification for Canister Length and Diameter}

The producer must demonstrate in the WCP that the strategy for meeting these specifications will meet the requirements of the WASRD.

\subsubsection{Length and Diameter Specification}

The overall length of the unfilled canister, after accounting for the closure method, shall be $3.000 \mathrm{~m}(+0.005 \mathrm{~m},-0.020 \mathrm{~m})$, including the neck and handling flange. The measured length of the unfilled canister shall be reported in the Production Records.

The outer diameter of the unfilled canister shall be $61.0 \mathrm{~cm}(+1.5 \mathrm{~cm},-1.0 \mathrm{~cm})$. The measured diameter of the unfilled canister shall be reported in the Production Records.

COMPLIANCE STRATEGY. The specified maximum and minimum length and diameter of the unfilled canister selected for the INEEL process have been designed to be safely within those required by this specification. As-built canister lengths and diameters will be provided for all production canisters.

IMPLEMENTATION. The INEEL will specify in the canister fabrication or equipment specification and in its contract drawing(s) the maximum and minimum prepour lengths and diameters for each production canister to ensure that they do not violate the range of length and diameter values mandated by this specification. Canister and parts dimensions will be specified in the documentation package for the selected canister design.

Similarly, the maximum diameter of the canister, about $61.0 \mathrm{~cm}$, plus that due to the weld bead character height must not exceed a value safely below the largest permissible canistered waste form diameter of 64.0 centimeters (see WAPS 3.11.2).

The canister dimensions of each as-built, unfilled canister will be measured at the canister (or parts) fabricator, and will be reported in the Production Records.

The impact of filling and sealing on canister length and diameter will be determined during fullscale filling tests with surrogate wastes. Also, information on the impact of canister filling and sealing at other waste immobilization facilities will be used to assess changes in physical dimensions of INEEL canisters subjected to these actions. 
DOCUMENTATION. The Production Records will provide the as-built measured lengths and diameters for all canisters. 


\section{CANISTERED WASTE FORM SPECIFICATIONS}

\subsection{Free-Liquid Specification}

The producer shall ensure that the canistered waste form does not contain detectable amounts of free liquids. The producer shall describe the method of compliance in the WCP and provide documentation of the ability to comply, and of the detection limits, in the WQR.

COMPLIANCE STRATEGY. The vitrification process will evaporate free liquid from the waste feed. The canisters will be inspected prior to entry into the vitrification facility to ensure they contain no drainable liquid. Administrative controls and timely permanent weld closure of the canister lid will ensure that free liquid cannot enter or condense inside the filled canister.

IMPLEMENTATION. Since the vitrification process will take place at temperatures well in excess of $1000^{\circ} \mathrm{C}$ and $<1$ atm pressure, all liquid in the waste feed will be evaporated from the glass. Any trace of free liquid residing in the empty canister is expected to evaporate as the canister is filled with the hot glass (temperatures $>1000^{\circ} \mathrm{C}$ ). The transition temperature (see Section 1.4) defines the temperature limit below which the glass is phase stable. This temperature is well in excess of the boiling point of any liquid that might reasonably be expected to contaminate the waste glass. Therefore, no free liquid would be expected within the glass up to that limit. Experiments to verify this assessment will be reported in the WQR. In these tests, simulated waste glass will be annealed for extended times at temperatures approximating the glass transition temperature and will be monitored for free liquid formation and release of condensable volatiles.

The ingress of free liquids and other prohibited materials into the canisters will be prevented by a series of procedures and specifications known as administrative controls. These controls include procurement and handling specifications requiring the canisters to be cleaned by the fabricator and protected from contamination during shipment. The canisters will be inspected and cleaned, if warranted, prior to transfer to the vitrification cell. In the cell, additional administrative procedures will prevent possible contamination by prohibited substances. Only dry inert cover gas or nitrogen will be used in the welding process, and no prohibited (see Section 3.2) gases will be intentionally introduced into the vitrification cell. Purging of the filled canister with dry inert gas just prior to welding the lid will also minimize the amount of condensible gases retained in the sealed canister. Temporary covers will be used to protect the mouth of the canister as well as its contents prior to welding from the entry of free liquids and solids.

The decontamination process is a potential source of free liquids in the canister. However, since canister lid weld closure and verification will precede the decontamination process (see Section 3.6), it will not be possible for contaminants to enter the canister. Furthermore, the use of dried gases to purge the filled canister before final lid weld closure can be used, if necessary, to prevent water vapor from condensing inside the canister (i.e., the dew point of any entrapped water vapor will be below the canister storage and anticipated repository temperatures).

DOCUMENTATION. The WQR and the Production Records will report on the absence of free liquids in the waste glass and on the controls used to prevent free liquids from entering the canistered waste form. 


\subsection{Gas Specification}

The producer shall ensure that the canistered waste form does not contain detectable amounts of free gas other than air, the residuals of air, noble and radiogenic gases. The internal gas pressure immediately after closure shall not exceed $150 \mathrm{kPa}\left(22\right.$ psia) at $25^{\circ} \mathrm{C}$. The producer shall describe the method of compliance in the WCP and provide documentation of the ability to comply with this specification, and of the detection limits, in the WQR. The producer shall also document in the WQR the quantities and compositions of any gases that might accumulate inside the canister from radiogenic decay or after the canister has been subjected to temperatures up to $500^{\circ} \mathrm{C}$.

COMPLIANCE STRATEGY. Glass pouring and permanent closure of the canister will be in an air atmosphere. In-cell atmospheric monitoring and administrative controls will be in place to ensure that gases other than air and cover gas (helium or argon) are not present in the cell where canister closure is performed, will be in place to prevent any undesirable gases from entering the canister during closure. Technical literature has been reviewed and shows that an insignificant amount of gas would be generated during storage below the glass transition temperature. An estimate of the type and amount of gases and water vapor present, if any, will be based on the results of an experiment wherein a canister filled with nonradioactive glass during a vitrification test is heated to the glass transition temperature. Any gases evolved will then be analyzed.

The amount of radiogenic gases that could be generated in a canister will be calculated based on the estimate of radionuclide content of the canister.

IMPLEMENTATION. The waste glass will be poured into the canister in an air environment. Final closure is planned to be at one atmosphere in air and/or inert cover or dry purge gases. Therefore, any void spaces will contain air and/or inert gases.

Data collected during the filled canister heating experiment described above and from other supporting research published in the literature will be compiled to provide estimates of the quantities and compositions of gases that could vaporize from the glass near the glass transition temperature. Since the glass will be stored well below the glass transition temperature (see Section 1.4), this information will provide an upper bound on the amount of anticipated volatility.

The literature review indicates that no significant amount of gas should accumulate inside the canister after closure as a result of the canister being heated to $500^{\circ} \mathrm{C}^{(9,10)}$. This is because the waste glass manufacturing temperatures are many hundreds of degrees above the specified $500^{\circ} \mathrm{C}$ temperature. Thus, any volatiles that could potentially pressurize the canisters during storage will have evolved during the melting process $^{(11)}$.

Numerous studies to investigate the volatility of glass components when exposed to high temperatures (primarily fires during production or transport ${ }^{(12)}$ ) have been conducted at the Pacific Northwest Laboratory. These studies used an apparatus in which air (either dry or moist) flowed past a heated sample and then past a water cooled "cold finger", where condensables were collected for chemical analysis. The heated sample was suspended from a balance, thus enabling the weight of the sample to be continuously monitored ${ }^{(13)}$. Typical volatiles from waste glasses at high temperatures $(800$

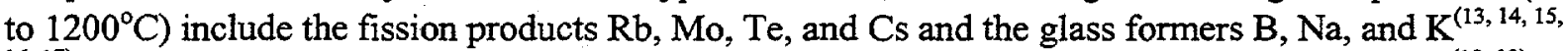
${ }^{16,17)}$. Cs was found to be the most volatile. Other studies have also confirmed these behaviors ${ }^{(18,19)}$.

Although Cs and other elements are released from the glass, the vapor pressures of the compounds that these elements will form (oxides, hydroxides, or alkali borates ${ }^{(19)}$ ) are extremely low at the $500^{\circ} \mathrm{C}$ 
temperature referred to in the specification. For example, alkali metal ( $\mathrm{Cs}, \mathrm{Li}, \mathrm{Na}, \mathrm{K}$ ) hydroxides have vapor pressures of $1 \mathrm{~mm} \mathrm{Hg}\left(0.0013 \mathrm{~atm}\right.$.) or less at temperatures between 700 to $750^{\circ} \mathrm{C}$, and volatility will not be significant. At the specified temperature of $500^{\circ} \mathrm{C}$, the vapor pressures of the compounds that will incorporate the volatilized elements will be even lower.

The amount of radon and helium produced from the decay chains of Th-232, U-234, U-235, U-238, and the higher actinides in a canister filled with HLW glass will be calculated. A canister with the upper bound radionuclide inventory (see Section 1.2.1) will be the basis for this calculation.

DOCUMENTATION. The WQR and the production records will report on the absence of prohibited free gases in the canistered waste form below the $500^{\circ} \mathrm{C}$ temperature limit and on the controls designed to prevent the ingress of these gases. Documentation of the amount and composition of gases due to radioactive decay will also be provided in both documents.

\subsection{Specification for Explosiveness, Pyrophoricity, and Combustibility}

The producer shall ensure that the canistered waste form does not contain detectable amounts of explosive, pyrophoric, or combustible materials. The producer shall describe the method of compliance in the WCP and provide documentation of, the detection limits, and the ability to comply with this specification for the range of waste types, in the WQR. The producer shall document in the WQR that the canister waste forms remain nonexplosive, nonpyrophoric, and noncombustible after having been subjected to temperatures up to $500^{\circ} \mathrm{C}$.

COMPLIANCE STRATEGY. Borosilicate glass does not contain any of the above material types. Prior to entry into the vitrification facility; the canisters will be inspected to ensure they do not contain any of these materials. Administrative controls and timely weld closure of the canister will prevent entry of prohibited materials into the canistered waste forms.

IMPLEMENTATION. Borosilicate glass, the INEEL HLW form, is oxidized and is not inherently explosive, pyrophoric, or combustible. It is phase stable up to the glass transition temperature and, even at $500^{\circ} \mathrm{C}$, will not change into these types of prohibited materials.

Prior to entry into the vitrification cell, the canisters will be visually inspected to ensure that they do not contain any prohibited materials. Verification that this inspection took place will be recorded in the Production records for each canister. Permanent weld closure after canister filling will ensure against ingress of explosive, pyrophoric, or combustible materials.

Based on estimates of the mass of gases that could be released, prolonged venting of canisters before, welding appears not to be required. Venting times will be recommended after appropriate experimentation is performed during process development.

DOCUMENTATION. The WQR will report on the absence of explosives, pyrophorics, and combustibles in the canistered waste form. The WQR will also present a detailed canister flow path from the vendor to the vitrification cell to on-site interim storage and will show there are no opportunities for these materials to enter the canister. Production records will also show that the absence of explosives, pyrophonics, and combustibles in the canister has been continued. 


\subsection{Organic Materials Specification}

The producer shall ensure that the canistered waste form does not contain detectable amounts of organic materials. The producer shall describe the method for complying with this specification in the $W C P$ and provide documentation of the ability to comply, and of the detection limits, in the WQR.

COMPLIANCE STRATEGY. Borosilicate glass is an inorganic material. Prior to entry into the vitrification facility, the canisters will be visually inspected to ensure that no obvious organic material is present. Administrative controls and permanent weld closure will prevent organics from entering the canister after glass filling.

IMPLEMENTATION. Because of the use of organics in the calcination and separations processes that precede vitrification, minor amounts of organics can be expected in the melter feed, but these will decompose in the melter. Standard test methods for assessing the amount of ash from organic materials, ASTM D482-80 and ASTM E830-81, use temperatures of 575 to $775^{\circ} \mathrm{C}$ to decompose the organic molecules. These temperatures are less than the operating temperature of the melter, which exceeds $1000^{\circ} \mathrm{C}$; therefore, no organics will remain in the glass.

The canisters will be cleaned, degreased, and visually inspected by the fabricator according to applicable sections of ASTM A380. Certification will be required from the fabricator (see Section 2.2), and receipt of this certification will be recorded in the Production records. Before use, the canisters will be stored in a clean, dry environment. Prior to entry into the vitrification facility, the canisters will be visually inspected to ensure that organics used during fabrication were removed. Production records will show that this inspection took place. Furthermore, the heat of the glass pouring into the canister will cause trace quantities of organics in the canister to decompose.

Administrative steps will be taken to control storage of organics in the vitrification facility and ensure lubricants and fluids from the processing and handling equipment cannot drip or spill into the canisters. In addition, the use of temporary covers while the canisters are in-cell will preclude the introduction of organics by minimizing the period that canisters are uncovered. Timely weld closure of the canister will further limit the possibility of contaminating the waste glass with organics. Samples of glass taken prior to closure during full-scale surrogate tests will be analyzed for total organic carbon to confirm the absence of organic material in a detectable amount ( $>10 \mathrm{ppm})$. Results of these analyses will be documented in the WQR.

DOCUMENTATION. The WQR will report on the controls to ensure that only insignificant quantities of organics are present in the canistered waste form. Analytical test data on simulated glass will be included to demonstrate compliance. Production records will also show that inspection for organic materials and confirmation of their absence has been completed by the fabricator and prior to entry in the vitrification facility.

\subsection{Chemcical Compatibility Specification}

The producer shall ensure that the contents of the canistered waste form do not cause internal corrosion of the canister, which could adversely affect normal handling during storage, or during an abnormal occurrence such as a canister drop accident. The producer shall describe the method of demonstrating compliance in the WCP. Interactions between the canister and its contents, including any reaction products generated within the canistered waste form after exposure to temperatures up to $500^{\circ} \mathrm{C}$, shall be discussed in the WQR. 
COMPLIANCE STRATEGY. Existing data and calculations will be used to show that the canister does not react with the solidified glass. Moisture content in the canister void space and its potential effect on canister corrosion will be estimated. Controls will ensure that water, a potential corrodent, will not be present within the canistered waste form. It will be demonstrated that the extent of corrosion is sufficiently low as to not affect the integrity of the canister.

MMPLEMENTATION. Evidence will be presented in the WQR to show that internal corrosion of the canister will be extremely minor as a result of the canister material being in contact with the glass waste form. First, it will be shown that reactions between the molten glass and the 304L stainless steel canister wall during filling are insignificant, a consequence of the short duration that the wall is subjected to elevated temperatures (i.e., less than four hours above $600^{\circ} \mathrm{C}$ ). Secondly, it will be argued on theoretical grounds that no significant chemical interactions would be expected to occur at temperatures up to $T_{g}$, the glass transition temperature. $T_{g}$ is the temperature below which a supercooled liquid structure is frozen and behaves as a glassy solid. For INEEL glass, this corresponds to a temperature of about $450^{\circ} \mathrm{C}$. Below $\mathrm{T}_{\mathrm{g}}$, crystallization/vitrification reaction kinetics become imperceptibly small, indicating that the rate of molecular or atomic movements are extremely low. Accordingly, chemical reactions between stainless steel and glass, which by necessity require the diffusion of reactants to the glass/metal interface and the diffusion of reaction products away from this interface, would be so slow below $T_{g}$ as to be nearly immeasurable.

The above theoretical assessment is confirmed experimentally by information collected by other researchers. In a study conducted by Oak Ridge National Laboratory, various canister and waste form materials were held in contact at temperatures of 100 and $300^{\circ} \mathrm{C}$ in air for periods of 6888 and 8821 hours $^{(20)}$. It was reported that no significant interaction was detected between a typical borosilicate waste glass and 304L stainless steel. This conclusion is based on a visual examination of the surface of the metal where it had been in contact with the glass, and the weights of the glass and metal before and after the test.

Other waste form-canister material compatibility studies have been conducted by the Savannah River Technology Center in support of the DWPF. In one study, a borosilicate waste glass was melted and cast in $304 \mathrm{~L}$ stainless steel crucibles. After being annealed at $500^{\circ} \mathrm{C}$ and furnace cooled, the crucibles were held at $350^{\circ} \mathrm{C}$ for 10,000 hours. A metallographic examination was used to determine the changes in the dimensions of cross sections of the crucibles that had been in contact with the glass. From this examination it was determined that no significant corrosion of the crucibles had occurred ${ }^{(21)}$. In a second series of tests no detectable corrosion was noted after the crucibles of glass had been held at $600^{\circ} \mathrm{C}$ for 20,000 hours ${ }^{(22)}$.

The presence of liquid water inside the canister could lead to localized corrosion (i.e., stress corrosion cracking) of 304L stainless-steel, especially if $\mathrm{Cl}^{-}$and $\mathrm{F}^{-}$leach from the glass. Internal liquid water corrosion, however, will not be a problem at the INEEL because weld closure soon after canister filling will prevent the entry of water into the canister during subsequent decontamination and storage operations. Additionally, purging the canister with dry cover gas prior to weld closure may be used to eliminate the possibility of trapped water vapor condensing inside the canister during storage.

The amount of corrosion that could result from moisture contained in the air in the canister void space after closure will be calculated. The approach will be to calculate the maximum weight loss of metal that could occur assuming that all of the water and oxygen in the canister airspace reacts with the canister wall. The calculated weight loss then will be converted to a penetration thickness to determine the extent of uniform corrosion. The kinetics of corrosion reactions will be ignored; only the ultimate extent of corrosion will be considered. Uniform and nonuniform corrosion such as intergranular corrosion, stress corrosion cracking, and pitting will be addressed. These calculations will be presented in 
the WQR and will demonstrate that the extent of corrosion is insignificant and, therefore, does not harmfully affect the strength and integrity of the canister.

DOCUMENTATION. The WQR will include an analysis of the extent of corrosion and chemical reactions between the inside of the stainless steel canister, the borosilicate glass waste form and other potential corrodents that may be contained within the sealed canister.

\subsection{Fill Height Specification}

The producer shall fill the canister to a height equivalent to at least $80 \%$ of the volume of the empty canister. The producer shall report this height in the Production records and describe the method of compliance in the WCP. Documentation supporting the selected method of compliance shall be provided in the WQR.

COMPLIANCE STRATEGY. The INEEL plans to fill its canisters to 85 percent of capacity. Several methodologies, such as neutron transmission, gamma emission detection, and thermal imaging, will be investigated to determine the correct fill height of each canister.

IMPLEMENTATION. The INEEL is planning to fill its canisters to a nominal fill height equivalent of 85 percent of the canister volume, with a range of 80 to 90 percent. The following are descriptions of systems, one of which, may be employed to measure or control fill height:

- The neutron transmission method senses the glass level directly, can detect intermediate thicknesses of glass indicative of uneven canister filling, and is independent of waste loading or level of radioactivity. The system is designed to detect the arrival of the glass level at the 40,60 , and 91 inches (corresponding to 85 percent fill) levels. Boron triflouride counting systems designed to signal the approach and arrival of the glass level are located at each elevation.

- The gamma level detection system measures gamma radiation emanating from radioactive isotopes incorporated in the canistered glass.

- The infrared thermal imaging system operates by remotely measuring thermal emissions from the canister surface and displaying the output on a high resolution color monitor. The infrared technology is undergoing laboratory tests to demonstrate accuracy; it is expected to be the principal in-process technique for monitoring fill height.

DOCUMENTATION. The WQR will report on the design of the primary and backup level detection system studies. For each production canister, the fill height as determined by detective system measurements will be reported in the Production records.

\subsection{Specification for Removable Contamination on External Surfaces}

The level of removable radioactive contamination on all external surfaces of each canistered waste form shall not exceed the following limits at the time of shipment:

Alpha radiation: $220 \mathrm{dpm} / 100 \mathrm{~cm}^{2}$

Beta and Gamma radiation: $2200 \mathrm{dpm} / 100 \mathrm{~cm}^{2}$ 
In addition, the producer shall visually inspect each canistered waste form and remove visible waste glass from the exterior before shipment. The producer shall describe the method of compliance in the WCP and provide contamination level results in the Storage and Shipping Records.

COMPLIANCE STRATEGY. The canistered waste form will probably be decontaminated by frit slurry blasting. The INEEL will smear survey the canister's external surfaces according to 10 CFR 71.87(I) before shipment to the repository. The external surfaces of the canistered waste forms will also be visually inspected for glass, and if present, the glass will be removed.

MPLEMENTATION. Before transfer to storage and to the repository, the external surface of the canister will be smeared according to the procedure in 10 CFR 71.87(I). It is anticipated that smearing will be done under the lifting flange, along the entire length of the canister body, and on the canister bottom. This procedure may be performed at two separate locations on the canister (about 180 degrees apart) to provide a representative measure of surface contamination. The smears will be counted using standard instruments. The results from each canister, prior to storage, will be recorded in the internal process log. Before shipment, the smear procedure will be repeated and the results reported in the Storage and Shipping Records. If any smear test result exceeds the specified limit, the canister will be decontaminated and smeared again.

Visual inspection of the canisters, either by direct observation through shield windows or via a television camera, will be made before shipment to ensure that no waste glass is adhering to the canister. Glass deposits should be readily visible, especially after canister decontamination, because of the large differences in reflectivity and color between the glass and the stainless steel canister. Since the decontaminated canister is silver in color ${ }^{(23)}$, it is unlikely that any sizable thickness of adhering nuclear waste glass would not be visible against this background. Thin sections of adhering glass, if present, would appear as heat discolored regions on the otherwise bright, silver-colored canister surface. The results of the surface inspection will be recorded in the internal process log. If glass is adhering to the canister before or after decontamination, it will be removed, possibly by use of a needle gun (a remote technique for glass removal). Smear tests would then be repeated to ensure compliance with contamination limits.

DOCUMENTATION. The WQR will detail the decontamination method, the amount of canister material removed, and the methods of visually inspecting and removing adhering visible waste glass from the exterior of the canister. The WQR will also discuss the smear procedure to be used to comply with this specification. The smear test results and visual inspection results affirming the absence of adhering glass for each canister will be provided in the Storage and Shipping Records.

\subsection{Heat Generation Specification}

The heat generation rate for each canistered waste form shall not exceed 1500 watts per canister at the year of shipment.

\subsubsection{Heat Generation Projections}

The producer shall document in the WQR the expected thermal output of the canistered waste forms and the range of expected variation for each waste type, indexed to the year 2015. The method to be used for demonstrating compliance shall be described by the producer in the WCP. Projections for compositions not available for reporting in the initial WQR shall be included in an addendum to the $W Q R$. 


\subsubsection{Heat Generation at Year of Shipment}

The producer shall report in the Storage and Shipping Records the estimated heat generation rate for each canistered waste form. The producer shall describe the method for compliance in the WCP.

COMPLIANCE STRATEGY. The heat generation rate in a canister containing HLW will be calculated using ORIGEN2. The heat generation rate depends on the amount and type of radionuclides contained in the canister and decreases with time as a result of radioactive decay. Data needed to compute the heat generation rate are the concentration of radionuclides in a canister. The source of these data is described in WQR Section 1.2.1. Radionuclide concentrations and the corresponding heating rates are computed in ORIGEN2 as a function of time, given the initial concentrations. A graph of heat generation rates as a function of number of years of decay will be produced. The heat generation rate in the year 2015 and at the time of shipment will be read from the graph.

IMPLEMENTATION. The heat generation rate in a canistered waste form is dependent upon the amount and type of radionuclides in the canister. The estimation of radionuclide inventory in a canistered waste is discussed in Section 1.2.1.

Variations in heat generation rates may be expected if the amount of HLW glass contained in the canister varies. Normally, the canisters will be filled to 85 percent of their volume, although it is permissible to fill only to 80 percent. In an off-normal condition, a canister may be filled to 100 percent of its volume so that the upper and lower bounds of the heat generation rates could be +15 or -5 percent, respectively, over the projected nominal heating rate. Batch-to-batch variations in feed composition will be estimated by pilot plant operations. The upper and lower bounds of heat generations will be adjusted accordingly, and an addendum to the WQR will be issued.

The projected radionuclide concentration in a canister will be input to ORIGEN2 to compute concentration and heating rate as a function of decay time. The projected heat generation rate in the year 2015 is expected to be less than 375 watts. The heating rate at the time of shipment will be read from the graph of heating rate as a function of time.

DOCUMENTATION. The WQR will include the expected thermal output indexed to 2015 and the range of expected variations for the canistered waste form based on calculations (with uncertainties) of the radionuclide inventory. If actual chemical analysis data on the waste is outside the range of projected values, an addendum to the $W Q R$ will be issued. The Storage and Shipping Records for each canister will contain the calculated heat generation rate of the canistered waste form.

\subsection{Specification for Maximum Dose Rates}

The canistered waste form shall not exceed a maximum surface (on contact) gamma dose rate of $10^{5} \mathrm{rem} / \mathrm{hr}$ and a maximum neutron dose rate of $10 \mathrm{rem} / \mathrm{hr}$.

\subsubsection{Projections of Dose Rates}

The producer shall report in the WQR the expected values and the range of expected variation for both gamma and neutron dose rates indexed to the year 2015. The producer shall describe the method for demonstrating compliance in the WCP. 


\subsubsection{Dose Rates at Time of Shipment}

The producer shall provide in the Storage and Shipping Records either the calculated or measured values for both gamma and neutron dose rates at the time of shipment for each canistered waste form. The producer shall describe the method of compliance in the WCP.

COMPLIANCE STRATEGY. Projections of gamma dose rates at the surface of HLW canisters will be made using ORIGEN2 and QADMOD ${ }^{(24)}$. ORIGEN2 provides the sources of neutrons and gamma radiation in the canister based on the type and amount of radionuclides present in the canister. Radionuclides estimated to be present in a canister as a function of time (several years into the future) will be computed, and the corresponding gamma sources will be used to compute dose rates in QADMOD. Dose rates in the year 2015 and in the year of shipment (not known at present) will be read from a graph of dose rates as a function of time (i.e., years). Neutron dose rates will be calculated using the source concentration at the time of interest.

Variations in dose rates may be expected if the amount of HLW in a canister varies. The canisters will be filled normally to 85 percent of its capacity even though WAPS requires the canister to be filled to a height equivalent at least 80 percent of its capacity. In an off-normal condition, a canister may be filled to 100 percent of its volume so that the upper and lower bounds of the dose rates could be +15 and -5 percent, respectively.

Another source of variation that could be expected is due to batch-to-batch variation in feed composition. There is currently no data on this batch-to-batch variation corresponding to radioactive operation. However, if one used the same assumption listed in Section 3.8 (i.e., 15 percent), the maximum dose rate could be 30 percent ( 15 percent overfill, 15 percent process variation) over the nominal dose rate and the lower bound about 20 percent $(5$ percent underfill, 15 percent process fluctuation) below the nominal dose rate. The nominal dose rates calculated will be increased by 30 percent to project the maximum values.

IMPLEMENTATION. Gamma and neutron surface dose rates for the canistered waste form depend on the radionuclide inventory and other properties of the glass such as chemical composition and density. The projected radionuclide inventory in the canistered waste will be estimated, as discussed in Section 1.2.1. The gamma and neutron source strength thus calculated will be input to QADMOD and supplemented with the ANISN computer code ${ }^{(25)}$. The energy dependent flux at the surface of the canister will be calculated assuming the source to be uniformly distributed inside the canister. The energy dependent neutron and gamma fluxes at the surface will then be converted into their respective dose rates using appropriate conversion factors. The expected dose rate and its variation will be based on the estimated range of radionuclide concentrations in a canister.

Dose rates at the time of shipment will be calculated by decaying the radionuclide to shipment time and computing dose rates. The results of these calculations will be used to estimate the dose rates at the time of shipment.

DOCUMENTATION. The expected dose rates and ranges of variation will be reported in the WQR based on estimates of radionuclide inventory. The calculated dose rates at the time of shipment for each canistered waste form will be reported in the Storage and Shipping Records. 


\subsection{Subcriticality Specification}

The producer shall design a waste form to ensure that, under normal and accident conditions, $a$ nuclear criticality accident is not possible unless at least two unlikely, independent, and concurrent or sequential changes have occurred in the conditions essential to nuclear criticality safety. The calculated effective neutron multiplication factor, $K_{\text {eff }}$, must be shown to be less than 0.90 after allowing for bias in the method of calculation and the uncertainty in the experiments used to validate the method of calculation. The producer shall describe the method of demonstrating compliance in the WCP and provide supporting documentation in the WQR. The WQR shall also include sufficient information on the nuclear characteristics, such as fissile density, of the canistered waste form to enable subcriticality to be confirmed under transportation, storage, and disposal conditions.

COMPLIANCE STRATEGY. $\mathrm{K}_{\text {eff }}$ for the canistered waste will be calculated using the $\mathrm{KENO}^{(26)}$ computer code. It will be shown that the calculated effective neutron multiplication factor after adjusting for uncertainties in the method of analysis, $\mathrm{K}_{\text {eff }}$ (the calculated effective neutron multiplication factor), is less than 0.90 .

$$
K_{\text {eff }(c a l)}+2 \_\sigma_{c a L}<0.9
$$

Where $\sigma_{\text {cal }}$ is the uncertainty and bias associated with method of calculation.

IMPLEMENTATION. The composition, radionuclide inventory including fissionable radionuclides, and fill volume of the canister will be estimated as explained in Sections 1.1, 1.2, and 3.6. These and the canister geometry will be input to the KENO computer code ${ }^{(26)}$. The KENO criticality analysis code will be validated using known experimental data from which code bias and method uncertainties will be obtained and quantified.

The validation will also include comparing known methodologies for selected analysis cases consistent with INEEL canistered HLW. The calculated reactivity of the canistered waste form will be shown to be significantly less than 0.90 , including the bias and uncertainties in the methods of analysis, such as Equation (1) above. Normal operating conditions and credible composition variations and storage scenarios at the INEEL will be considered.

The WQR will report the reactivity for the compositions (see Section 1.1.1) that are most likely to be a criticality concern (lowest boron). The amount of fissionable radionuclides used in this analysis will be conservatively based on a canister with maximum fissionable material loading and lowest possible boron content and will assume the fissionable material is uniformly dispersed in the glass matrix. The fissile quantities (or content) of the canistered waste used for the analyses will be based on the radionuclide inventory estimates (projections).

DOCUMENTATION. The WQR will present analyses showing that the effective multiplication factor of the canistered waste form is much less than 0.90 for conditions likely to be encountered at the INEEL. The report will also include sufficient information on the nuclear characteristics of the canistered waste form for repository design purposes. 


\subsection{Specifications for Weight and Overall Dimensions}

The configuration, dimensions, and weight of the canistered waste form shall not exceed the maximum size and weight which can be received, handled, and emplaced in the repository. These parameters shall be controlled as indicated below and shall be documented at the time of shipment. The producer shall describe the method of compliance in the WCP and the basis for compliance in the WQR.

\subsubsection{Weight Specification}

The weight of the canistered waste form shall not exceed $2,500 \mathrm{~kg}$. The measured weight and estimated error shall be reported in the Storage and Shipping Records.

COMPLIANCE STRATEGY. The glass filled canisters will be weighed and the errors estimated before shipment to the repository.

MPLEMENTATION. The canistered waste forms will be weighed on a scale in the INEEL shipment area prior to shipment to a monitored retrievable storage facility or repository. It is anticipated that the weight of a canister filled to a level of 85 percent will be about $1900 \mathrm{~kg}$. The scale will be calibrated and the errors recorded. The maximum canistered waste form weight will be less than $2500 \mathrm{~kg}$; this weight will be at approximately midscale. Errors in weight for the range of acceptable fill heights in the canister (see Section 3.6) will be estimated.

DOCUMENTATION. The WQR will report on the scale, calibration procedures, and results. Canistered waste form weights and estimated errors will be recorded in the Storage and Shipping Records.

\subsubsection{Specification for Overall Dimensions}

The dimensions of the canistered waste form shall be such that, at the time of shipment, the canistered waste form will stand upright without support on a flat horizontal surface and will fit completely without forcing when lowered vertically into a right-circular, cylindrical cavity, $64.0 \mathrm{~cm}$ in diameter and $3.01 \mathrm{~m}$ in length.

The producer shall estimate in the WQR the minimum canister wall thickness of the filled, decontaminated canister. The producer shall also provide in the WQR an estimate of the amount of canister material that is removed during surface decontamination and the basis for that estimate. The producer shall document the unfilled canister wall thickness in the Production records.

COMPLIANCE STRATEGY. Canisters filled during nonradioactive testing and during production at the INEEL will be inserted into a test cylinder with dimensions, as given in the specification. The minimum canister wall thickness will be determined from ultrasonic measurements taken on canisters filled during nonradioactive runs, minus the $304 \mathrm{~L}$ material loss due to the decontamination process. Ultrasonic wall thickness measurements on the as-manufactured canisters will be made.

IMPLEMENTATION. The INEEL will procure a stainless steel cylinder gauge with an inner diameter and length of 64.0 centimeters and 301 centimeters (corrected to $70^{\circ} \mathrm{C}$ ), respectively. Selected nonradioactive canisters filled during qualification testing and all radioactive waste canisters before shipment will be inserted into this test cylinder to verify that the canister fits without forcing and meets the maximum dimensional specifications. Before insertion into the shipping casks, the waste canisters will be placed on a flat, horizontal surface to assess their ability to stand upright. 
The minimum filled canister wall thickness estimate will account for thickness loss from both the decontamination process and from contact and corrosion with glass. This data will be obtained from ultrasonic gauge wall thickness measurements taken on canisters filled with nonradioactive glass during full-scale cold testing, minus estimated wall thickness losses due to the decontamination process (see Section 3.7) as determined from experimental studies.

Wall thicknesses will be determined on the as-manufactured, unfilled canisters at the time of fabrication. This data will be provided in the Production records.

DOCUMENTATION. The WQR will contain details on wall thickness measurements of the asmanufactured canister and estimated minimum wall thicknesses of the filled and decontaminated canister. The wall thickness of each unfilled canister will be included in the Production records. The Storage and Shipping Records will document all canister test results from the overall dimensions (cylinder) test and the upright stand test.

\subsection{Drop Test Specification}

The canistered waste form shall be capable of withstanding a 7 meter drop onto a flat, essentially unyielding surface without breaching (leak rate $<1 \times 10^{-4}$ atm-cc/sec helium). The producer shall describe the method of compliance in the WCP and provide test results and any supporting analyses in the WQR. The test results shall include information on measured canister leak rates and canister deformation after the drop.

COMPLIANCE STRATEGY. If DWPF or WVDP canister is adopted for containing INEEL glass, drop test infromation for that canister will be used and placed in the WQR because each of these canisters has been shown to meet the specification. If the adopted canister must be modified significantly then, the strategy for compliance with this specification will consist of two approaches: (1) using engineering calculations to form a basis for concluding that the reference canister can survive a 7 -meter drop and (2) dropping nonradioactive glass-filled canisters to confirm their ability to withstand the required drop.

IMPLEMENTATION. Engineering calculations will be performed using the finite element stress analysis method. A computer model of the filled reference canister will be created and impact analyses performed to simulate the required drop test.

In addition, at least three full scale canisters, filled with nonradioactive glass to about an 85 percent fill height, will be dropped from a height of 7 meters onto a flat, essentially unyielding surface with the center of gravity over the bottom center. This drop orientation has the highest potential drop height during canister handling. This drop orientation occurs if the canister is dropped while being unloaded from the transportation cask in such a manner that it falls back into the cask. Prior to the test, the reference lid will be welded to seal the canister. Post-impact leak tests will be conducted using the Helium Mass Spectrometer Leak Testing method in accordance with ASME Boiler and Pressure Vessel Code-Section V, article 10. Strain on the canister in the vicinity of the impact will also be characterized.

DOCUMENTATION. The results of canister finite element impact analyses and the qualification drop tests will be reported in the WQR. 


\subsection{Handling Features Specification}

The canistered waste form shall have a concentric neck and lifting flange. The lifting flange geometry and maximum loading capacity shall be described in the WCP.

The producer shall design a grapple, suitable for use at the repository, which satisfies the following requirements:

(a) The grapple shall be capable of being remotely engaged and disengaged from the flange.

(b) The grapple, when attached to a suitable hoist, and when engaged with the flange, shall be capable of raising and lowering a canistered waste form in a vertical direction.

(c) The grapple shall be capable of engaging and disengaging the canister flange within a right-circular cylindrical cavity with a maximum diameter of $62.5 \mathrm{~cm}$.

(d) The grapple shall be designed to prevent an inadvertent release of a suspended canistered waste form when the grapple is engaged with the flange.

The producer shall describe the grapple in the WCP and provide the designs in the WQR.

COMPLIANCE STRATEGY. WVDP and SRS will have two proven canister and corresponding grappler designs by the time the INEEL commences vitrification operations. During conceptual design of the INEEL vitrification process, the compatibility of these two canister designs with the INEEL process will be assessed. The most compatible of these designs will be selected for use by the INEEL to minimize development costs. The corresponding grapple design will similarly be adopted for use at the INEEL. Using an existing, qualified design will reduce the cost of developing the INEEL's vitrification process by eliminating the need to design and test a new grapple and develop procedures for operating the device. It may even be possible to eliminate fabrication costs by acquiring spare grapples for use at the INEEL. Repository operations will be simplified by reducing the number of different types of hardware and associated procedures required for handling HLW canisters.

IMPLEMENTATION. WVDP and SRS will have developed and qualified grappling devices for handling their HLW canisters prior to vitrification operations at the INEEL. During conceptual design of the INEEL's vitrification process, the WVDP and SRS canister designs will be evaluated for compatibility with the INEEL process, and one will be selected for use at the INEEL. The grappling device designed for use with the selected canister will also be adopted for use. If the WVDP design is selected, grapples should be readily available since the WVDP vitrification facility will likely be decommissioned before the INEEL's facility is built. Decommissioned WVDP grapples should be sent to the INEEL for storage in case the WVDP canister design is selected for use at the INEEL.

DOCUMENTATION. The detailed design of the selected remote grapple, the codes and standards controlling design, the drawings and specifications used for fabrication, and the acceptance test results will be incorporated in the WQR via references to the documentation used to qualify the original design. 


\section{QUALITY ASSURANCE SPECIFICATION}

The QA specification is divided into two parts: Part 1-Quality Assurance Program, and Part 2-Action Plan for Correction or Disposition of Nonconforming Waste Forms.

\subsection{Part 1-Quality Assurance Program}

The producer shall establish, maintain, and execute a $Q A$ program that applies to the testing and analyzing activities that demonstrate compliance with these WAPS during waste form qualification, production, handling, storage, and preparation for shipment. The producer shall impose a QA program consistent with the $Q A$ requirements that govern $H L W$ as identified in the DOE-RW Quality Assurance Requirements and Description $(Q A R D)^{(27)}$ and the Civilian Radioactive Waste Management System's WASRD ${ }^{(28)}$.

COMPLIANCE STRATEGY. In compliance with this specification, the INEEL has developed the INEEL SNF/Nuclear Material (NM) Quality Program Plan (QPP). This SNF/NM QPP incorporates the applicable requirements of DOE-RW QARD ${ }^{(27)}$ and the DOE-RW System's WASRD ${ }^{(28)}$. The QA requirements from these documents will pass from DOE-Headquarters through the DOE-Idaho Operations Office (-ID) to the Lockheed Martin Idaho Technologies Company (LMITCO). They are contained in INEEL SNF/NM QPP, which describes the QA requirements that need to be carried out by LMITCO through its subtier documents and procedures.

IMPLEMENTATION. The implementation of this compliance strategy consists of three elements: (1) developing the SNF/NM QPP; (2) identifying and SNF/NM Program, QARD applicable items, services, and activities; and (3) developing methods for using data and data sets generated prior to implementing INEEL's current QA program.

Throughout the evolutionary stages of INEEL's R\&D activities, contact will be maintained with other DOE facilities performing similar work. This interface will allow the INEEL to benefit from lessons learned by other DOE facilities. Program development and possible use of existing vendors and QA services from those facilities, such as cost-saving services in the area of purchasing and the production of canisters and melters for the vitrified waste forms, may also be possible. Other potential cost savings are evident and will be incorporated when practical.

\subsubsection{SNF/NM QPP Development}

The INEEL SNF/NM QPP describes, in its current revision, SNF/NM QA requirements for the INEEL HLW Immobilization Program, as well as LMITCO's application of DOE SNF/HLW QA program requirements. It also identifies the internal organizations using these requirements and those needing to add them to their departmental procedures. These SNF/NM QA requirements are carried out by LMITCO's procedural system. The SNF/NM QPP also describes the Waste Acceptance Process as consisting of developmental, qualification, production, and storage and shipout activities. The required documentation for the Waste Acceptance Process is the WCP, WQR, Production Records, and Storage and Shipping Records.

The INEEL SNF/NM QPP baseline criteria are derived from the requirements of 10 CFR 830.120, "Quality Assurance" and DOE Order 5700.6C, "Quality Assurance." The QARD ${ }^{(27)}$ also contains concepts pertinent to SNF/NM items, services, and activities. Those concepts will be reviewed for relevance and could be incorporated into the SNF/NM QPP. SNF/NM QA requirements will then be developed for those activities, items, and services essential to the Waste Acceptance Process. 
The charter for the INEEL's QA Program is LMITCO's Quality Assurance Program Description (QAPD) document, which responds to DOE Order 5700.6C, "Quality Assurance;" 10 CFR 830.120, "Quality Assurance Requirements;" and DOE-RW-0333 P, "Quality Assurance Requirements and Description." The QAPD is the foundation document of LMITCO's QA Program. Its contents set up the envelope for operation of the QA program at the INEEL.

\subsubsection{Identification of DOE-RW QARD Applicable Items, Services, and Activities}

The following is LMITCO's process for identifying specific items, services, and activities to which the increased QA requirements of the QARD may apply. First, criteria are set up to define those items, services, and activities which affect the ability to produce a canistered waste form that meets WAPS requirements. Next, an in-depth review of the INEEL's canistered waste form production process will be performed. It will be inclusive from waste form development to ship-out and will be conducted to determine items, services, activities, and associated equipment required to produce an acceptable canistered waste form. The above criteria are then applied to those items, services, and activities. A baseline list of INEEL's SNF/NM Items, Services, and Activities will then be developed.

This list will serve as an internal LMITCO reference document for new tasks and will show (1) whether the proposed new task has been reviewed for QARD relevance and (2) the result of that review (i.e., whether any of the increased QA requirements apply). As tasks that do not appear on the baseline list are started, they will be screened for QARD relevance via a process incorporated into LMITCO's procedures. The INEEL SNF/NM Items List will then be revised and re-issued under LMTCO's document control procedures.

\subsubsection{Qualification of Existing Data}

Data pertinent to WAPS compliance efforts were developed by the INEEL before implementation of a SNF/NM QPP and under other QA Programs not meeting the increased QA requirements of the QARD. These data sets fall within the scope of existing data, as defined by the QARD, and must be qualified prior to use in support of the Waste Acceptance Process. These data sets include results of work performed at the INEEL. To ensure the above data sets are suitable for their intended use, LMITCO has developed a qualification process incorporating the methods identified in NUREG-1298, "Determination of Equivalent Controls, Corroborating Data, Confirmatory Testing, and Peer Review (28) ". This qualification process follows LMITCO's departmental procedures and is applicable to those sets of data directly supporting the WQR. These data sets will be identified as WQR sections and placed in data packages that will be released for use following completion of the qualification process.

\subsection{Part 2-Action Plan for Nonconforming Waste Forms}

The producer shall submit an action plan, signed by authorized personnel through EM to DOE-RW for the correction or disposition of nonconforming waste forms for verification and documented approval from $R W$.

COMPLIANCE STRATEGY. INEEL will identify any canistered waste forms that are not in complete compliance with the WAPS. LMITCO will then notify DOE-ID and submit a proposed plan for dispositioning the nonconformance. After obtaining the required approvals, the disposition will be carried out per the QARD requirements. The documentation will then be placed in the Production Record of the nonconforming canistered waste form. 
IMPLEMENTATION. Some canistered waste forms may not, in all respects, comply with the WAPS requirements. Within the INEEL, these nonconformances will be identified and documented under the SNF/NM QPP section that discussed the control of nonconforming items. The process by which the INEEL will inform appropriate DOE organizations of the existence of a nonconforming canistered waste form is described below.

1. After identifying and documenting the nonconformance(s) under the SNF/NM QPP section on control of nonconforming items, LMITCO will inform DOE-ID, in writing, of the nonconforming canistered waste form. This notification will include the canister's unique identification and the specification requirement(s) with which it may not comply. DOE-ID will inform other affected DOE organizations as appropriate.

2. LMTTCO will then prepare an action plan for the nonconforming canistered waste form and submit it to DOE-ID for concurrence. That action plan will contain the canister identification, the specification requirement(s) with which it may not be in compliance, a description of the nonconformance, and a proposed disposition action that will allow safe shipment and handling of the nonconforming canistered waste form.

3. The DOE-D will send the action plan to DOE-EM-343 for the required concurrence.

4. LMITCO will incorporate appropriate comments, if any, and retransmit the proposed action plan to DOE-ID.

5. Following formal approval of the action plan, LMITCO will carry out the proposed disposition. LMITCO will then forward the completed nonconformance and disposition documentation for inclusion with the Production Records and/or Storage and Shipping Records of that specific canistered waste form. 


\section{DOCUMENTATION AND OTHER REQUIREMENTS}

\subsection{Specification for Waste Acceptance Documentation}

The following waste acceptance documentation shall be developed by the waste producer, maintained as permanent records, and provided to $R W$.

\subsubsection{Waste Form Compliance Plan}

The WCP shall describe the Producer's plan for demonstrating compliance with the requirements of the WAPS, including tests, analysis and process controls to be performed by the producer and records to be provided as evidence.

\subsubsection{Waste Form Qualification Report}

The WQR shall compile the results from waste form testing and analysis to demonstrate the ability of the producer to comply with the requirements of the WAPS.

\subsubsection{Production Records}

The Production records shall describe each canistered waste form through production.

\subsubsection{Storage and Shipping Records}

The Storage and Shipping Records shall describe the physical attributes of each canistered waste form and identify any abnormal events, such as thermal excursions, which have occurred during storage.

COMPLIANCE STRATEGY. This WCP addresses only WAPS Specification 5.1.1, since Specification 5.1.2 - 5.1.4 are not required to appear in the WCP or the WQR.

The INEEL will provide the WCP, WQR, Production Records, and Storage and Shipping Records to the DOE. These records will be maintained as controlled documents.

MPLEMENTATION. The WAPS requires four types of documentary evidence to be provided to the repository program for acceptance of the WVDP waste form: a WCP, a WQR, Production Records, and Storage and Shipping Records. All required documentation will be controlled in accordance with the requirements of DOE-RW, "Quality Assurance Requirements and Description ${ }^{(27)}$," and INEEL implementing procedures. The WCP and WQR will be reviewed by DOE-ID and DOE-EM prior to transmittal to DOE-RW.

The WCP provides a strategic description of the methods to be used to demonstrate compliance with each specification in the WAPS. The WCP contains an introduction section that reviews the process recommended to treat the HLW at the INEEL, five sections that detail the INEEL's response to the WAPS, a list of references, and an addendum (glossary) defining terms and acronyms used in the report. The organization of the WCP parallels that of the WAPS. For each WCP section, the WAPS specification number and text is reproduced verbatim. A brief general description of the INEEL's compliance strategy follows, with a more detailed discussion of that strategy in the implementation section. Finally, there is a documentation overview, which lists the documents required for compliance with that specification and the data that will be presented in those documents. 
The WQR is a compilation of the results of those testing and analysis programs identified in the WCP. The objective of the WQR is to confirm and document, in detail, the ability of the INEEL's process for immobilizing HLW to produce an acceptable product that meets specifications. The WQR will be used to gain approval for the start of waste form production and will supply information for the repository licensing process. The WQR will be prepared in sections, each corresponding to a specification in the WAPS. The organization of each WQR section will parallel the corresponding section in the WCP. Each section will contain a verbatim restatement of the specification, a summary of the INEEL's compliance strategy, a detailed description of activities and analyses performed, data compiled to implement the compliance strategy, and, if appropriate, an overview of the documentation describing the data to be included in the Production Records and or Storage and Shipping Records.

The Production Records and the Storage and Shipping Records will consist of documentation describing the contents and characteristics of specific individual canistered waste forms. These records will contain data summarizing the production history of each canistered waste form, including canister fabrication, glass batching, melter operation, canister filling, weld sealing of the filled canister, storage of the canistered waste form to prevent temperature excursions above $400^{\circ} \mathrm{C}$, loading into a shipping cask, etc. These controlled documents will be the primary documentary evidence that individual canistered waste forms have satisfied the WAPS. The contents of the Production Records and the Storage and Shipping Records are given in Tables 5-1 and 5-2, respectively. The Production, Storage, and Shipping Records will be provided to DOE.

The INEEL will establish and maintain a protocol, consistent with the QARD, for administering controlled documents, such as the WCP and WQR. Implementing procedures will define the systematic program for the preparation, review, approval, issuance, and revision of controlled documents. Controlled documents will also be subject to a change control process.

The WCP, WQR, Production Records, and Storage and Shipping Records will be retained as lifetime QA records. Complete lifetime records are documents that, in general, will receive no further entries but whose revision, when required, will be subject to a change control process. These records will be retained for the lifetime of the project and turned over to the DOE and/or the National Archives and Records Administration upon completion.

DOCUMENTATION. The WCP, WQR, Production Records and the Storage and Shipping Records for the HLW form will be prepared by the INEEL and provided to the DOE. 
Table 5-1. Content of production records.

\begin{tabular}{|c|l|}
\hline Specification & Production Record Information \\
\hline 1.1 .2 & Chemical analysis of glass chemistry (for all elements $>0.5$ wt\%, excluding oxygen). \\
\hline 1.2 .2 & Estimates of the reportable radionuclide inventory based on analyses of glass shards. \\
\hline 1.3 & $\begin{array}{l}\text { Chemical composition of approximately } 30 \text { glass samples (see Specification } 1.1 .2 \\
\text { above), the 95/95 tolerance interval for the corresponding } \Sigma \text { 's, the high value for } \\
\text { predicted PCT over the glass population, the comparison to the EA value, the predicted } \\
\text { PCT results for each of the glass samples, the mean of these predicted PCT results, and } \\
\text { the verification of production glass compliance with the specification. }\end{array}$ \\
\hline 1.5 & $\begin{array}{l}\text { A hazardous waste manifest if the waste form is found to be hazardous, including } \\
\text { appropriate Land Disposal Restriction (LDR) notification. }\end{array}$ \\
\hline 2.1 & Certified materials test reports for all canister materials comprising each canister. \\
\hline 2.2 & $\begin{array}{l}\text { Canister procurement documents, closure weld parameters, and visual weld inspection } \\
\text { results. }\end{array}$ \\
\hline 2.3 & Unique identification code for each canister. \\
\hline 2.4 & As-built length and diameter for each canister. \\
\hline 3.6 & Fill height of each canister. \\
\hline 3.11 & Unfilled canister wall thicknesses. \\
\hline 4.0 & Nonconforming documentation, if applicable. \\
\hline
\end{tabular}

Table 5-2. Content of Storage and Shipping Records.

\begin{tabular}{|c|l|}
\hline Specification & Production Record Information \\
\hline 1.4 & Certification that the waste form temperature after vitrification has not exceeded $400^{\circ} \mathrm{C}$. \\
\hline 2.3 & Verification of label(s) legibility for each canister. \\
\hline 3.7 & $\begin{array}{l}\text { Smear test results for each canister and verification that no visible glass remains on the } \\
\text { surface. }\end{array}$ \\
\hline 3.8 .2 & Estimated heat generation rate. \\
\hline 3.9 .2 & Estimated gamma and neutron dose rates for each canister. \\
\hline 3.11 & $\begin{array}{l}\text { Weight of filled canisters and estimated errors. Verification that canister will stand } \\
\text { upright and will fit without forcing into test cylinder. }\end{array}$ \\
\hline 4.0 & Nonconforming documentation, if applicable. \\
\hline
\end{tabular}




\section{REFERENCES}

1. Lockheed Idaho Technologies Company, ICPP Radioactive Liquid and Calcine Waste Technologies Evaluation Final Report and Recommendation, INEL-94/0119, 1995.

2. U.S. Department of Energy-Office of Environmental Management, Waste Acceptance Product Specifications for Vitrified High-Level Waste Forms, EM-WAPS, Rev. 2, 1996.

3. Jantzen, et al., Characterization of the Defense Waste processing Facility (DWPF) Environmental Assessment (EA) Glass Standard Reference Material (U, WSRC-TR-92-346, Revision 1, Westinghouse Savannah River Company, 1993.

4. Jantzen, C. M., Nuclear Waste Product Consistency Test Method Version 5.0, WSRC-TR-90-539, Westinghouse Savannah River Company, 1992.

5. 40 CFR 261, "Identification and Listing of Hazardous Waste," Code of Federal Regulations, Office of the Federal Register, July 1992.

6. $\quad 55$ FR 26986, “Amended Toxicity Characteristics," Federal Register, U.S. Nuclear Regulatory Commission, June 29, 1990.

7. Kent, J. C. and K. L. Shifty, Listed Waste Determination Report, WINCO 1132, Westinghouse Idaho Nuclear Company, 1993.

8. ASTM 1.01, 1.03, 1.04, 1.05-1987, "Annual Book of ASTM Standards," American Society for Testing and Materials.

9. Mendel, J. E., "Waste Glasses - Requirements and Characteristics," Proceedings of ANS Topical Meeting on the Treatment and Handling of Radioactive Wastes, Richland Washington, 1982.

10. Mendel, J. E., et al., "Evaluation of Conditioned High-level Waste Forms," Proceedings of an International Conference, Seattle, Washington, May 16-20, 1983.

11. Mendel, J. E., The Storage and Disposal of Radioactive Waste as Glass in Canisters, PNL-2764, Pacific Northwest Laboratory, 1978.

12. Rusin, J. M., A Review of High-level Waste Form Properties, PNL-3035, Pacific Northwest Laboratory, 1980.

13. Gray, W. J., Volatility of a Zinc Borosilicate Glass Containing Simulated High-Level Radioactive Waste, BNWL-2111, Pacific Northwest Laboratory, 1976.

14. Gray, W. J., Volatility of Some Potential High-level Radioactive Waste Forms, Radioactive Waste Management 1, 1980.

15. Mendel, J. E., et al., A State-of-the-art Review of Materials Properties of Nuclear Waste Forms, PNL-3802, Pacific Northwest Laboratory, 1981

16. Ross, W. A., et al., Annual Report on the Characterization of High-Level Waste Glasses, PNL-2625, Pacific Northwest Laboratory, 1978. 
17. Wald, J. W., et al., Comparative Waste Forms Study, PNL-3516, Pacific Northwest Laboratory, 1980.

18. Hastie, J. W., Vaporization of Simulated Nuclear Waste Glass, NBSIR83-2731, United States National Bureau of Standards, 1983.

19. Terai, R. and E. Kosaka, Volatilization of Low Temperature Borosilicate Glasses for High-Level Radioactive Wastes at Elevated Temperatures, ORNL-TR-4629, Oak Ridge National Laboratory, 1976.

20. McCoy, H. E., Studies of Waste-Canister Compatibility, ORNL/TM-8491, Oak Ridge National Laboratory, 1983.

21. Angerman, C. L. and W. N. Rankin, "Durability of Containers for Storing Solidified Radioactive Wastes," Corrosion/77 NACE Meeting, San Francisco, CA, March 14 - 18, 1977, National Association of Corrosion Engineers, Houston, Texas.

22. Rankin, W. N., "Prediction of the Lifetime of Canisters for Solidified Radioactive Waste," Presented at the meeting of the National Association of Corrosion Engineers, El Paso, Texas, October 28-30, 1980.

23. Westerman, R. E., An Investigation of Canister Label Legibility Following Simulated Decontamination Treatments, WVNS-DP-008, West Valley, 1990.

24. Price, J. H. and W. G. M. Blattner, Utilization Instructions for QADMOD-G, CCC-396, Oak Ridge National Laboratory, 1980.

25. Radiation Shielding Information Center, Multigroup 1-Dimensional Discrete Ordinate Transport Code with Anisotropic Scattering, CCC-254, Oak Ridge National Laboratory, 1975.

26. Greene, N. M. and L. M. Petrie, Multigroup Monte Carlo Criticality Program with SuperGrouping, SCALE, A Modular Code System for Performing Standardized Computer Analyses for Licensing Evaluation, NUREG/CR-0200, Vol. 2, 1983.

27. U.S. Department of Energy-Office of Civilian Radioactive Waste Management, Quality Assurance Requirements and Description, DOE/RW-0333P, Rev. 5, 1995.

28. U.S. Department of Energy-Office of Civilian Radioactive Waste Management, Waste Acceptance System Requirements Document, DOE/RW-0351P, Rev. 1, 1994.

29. Determination of Equivalent Controls, Corroborating Data, Confirmatory Testing, and Peer Review (NUREG-1298), 1988. 